\title{
SYNTHESIS, CHARACTERIZATION AND BIOLOGICAL EVALUATION OF INDOLE DERIVATIVES BEARING BENZIMIDAZOLE/BENZOTHIAZOLE MOIETY
}

\author{
BASAVARAJ SHIVABASAPPA NARABOLI, JAYAPRAKASH SHARANAPPA BIRADAR*
}

Department of Studies and Research in Chemistry, Gulbarga University, Kalaburagi 585106, Karnataka, India

Email: jsbiradar@rediffmail.com

Received: 06 May 2017 Revised and Accepted: 19 Jun 2017

\section{ABSTRACT}

Objective: The present work deals with the synthesis and characterization of biologically active new indole derivatives viz., $2-((1 H-$ benzo[d]imidazol-2-yl)thio)- $N$-(4-(3-(1H-indol-3-yl)acryloyl)phenyl)acetamide $6 a-d, \quad N$-(4-(3-(1H-indol-3-yl)acryloyl)phenyl)-2-((5-methoxy-1Hbenzo[d]imidazol-2-yl)thio)acetamide 7a-d and $N$-(4-(3-(1H-indol-3-yl)acryloyl)phenyl)-2-(benzo[d]thiazol-2-ylthio)acetamide 8a-d.

Methods: All these newly synthesized compounds were screened for their in vitro antimicrobial activity by an agar plate diffusion method, antioxidant activities: like 1,1-diphenyl-2-picryl hydrazyl (DPPH) radical scavenging activity (RSA), ferric ions $\left(\mathrm{Fe}^{3+}\right)$ reducing antioxidant power (FRAP), ferrous $\left(\mathrm{Fe}^{2+}\right)$ metal ion chelating activity.

Results: The structures of all the newly synthesized compounds were characterized by their IR, ${ }^{1} \mathrm{HNMR}$, mass spectral studies and elemental analysis. Compounds $6 \mathrm{~b}, 7 \mathrm{a}, 7 \mathrm{~b}, 8 \mathrm{a}$ and $8 \mathrm{~b}$ exhibited good radical scavenging activity (RSA) at a concentration $100 \mu \mathrm{g} / \mathrm{ml}$, compounds $7 \mathrm{~b}, 7 \mathrm{c}, 7 \mathrm{~d}$ and $8 \mathrm{~b}$ displayed good ferric ions $\left(\mathrm{Fe}^{3+}\right)$ reducing antioxidant power (FRAP) at a concentration $100 \mu \mathrm{g} / \mathrm{ml}$, compounds $7 \mathrm{~b}, 7 \mathrm{~d}, 8 \mathrm{~b}$ and $8 \mathrm{~d}$ showed good ferrous $\left(\mathrm{Fe}^{2+}\right)$ ion metal chelating activity. Compounds $7 \mathrm{~d}$ and $8 \mathrm{~d}$ exhibited good activity against all the screened bacteria and fungi.

Conclusion: The synthesised compounds $7 \mathrm{~d}$ having methoxy group at 5 positions of benzimidazoles ring, bromo group at 5 positions of indole ring, and $8 \mathrm{~d}$ having bromo group at position 5 of indole ring, both the compounds have exhibited potent antimicrobial activity. Some compounds have shown very good antioxidant activity.

Keywords: Indole, Benzimidazole, Benzothiazole, Antimicrobial, Antioxidant

(C) 2017 The Authors. Published by Innovare Academic Sciences Pvt Ltd. This is an open access article under the CC BY license (http://creativecommons.org/licenses/by/4.0/) DOI: http://dx.doi.org/10.22159/ijpps.2017v9i8.19725

\section{INTRODUCTION}

Many derivatives of indole were synthesized, and their biological activities were validated by in vitro or in vivo methods $[1,2]$. Indoles and its biheterocycles are featured in a wide variety of biological and pharmacologically active compounds [3]. The indole derivatives are known to possess anticancer [4,5], antioxidant [6, 7], anti-inflammatory $[8,9]$, antiviral [10], and antihypertensive [11] activities.

Benzimidazole is an important pharmacophore and a privileged structure in medicinal chemistry. It has been found to possess antioxidant [12], anti-inflammatory [13], diuretic [14], JAK1selective inhibitor [15], angiotensin II receptor antagonist [16] antiviral [17], anticonvulsant [18], and antidiabetic [19] activities.

Benzothiazole is also a heterocyclic compound, with diverse biological activities and is of extreme scientific interest. This heterocycle exhibits different biologic activities such as antibacterial [20], antifungal [21], anticancer [22], antioxidant [23], and tubulin polymerization inhibitor [24] activities.

Bearing in mind the above reports of bioactive indole and benzimidazole/benzothiazole, we reported herein the synthesis of the indole and benzimidazole/benzothiazole nucleus, in anticipation to get molecules with enhanced biological activities. All the newly synthesized compounds were screened for their antioxidant activities: like 1, 1-diphenyl-2-picryl hydrazyl (DPPH) radical scavenging activity (RSA), ferric ions $\left(\mathrm{Fe}^{3+}\right)$ reducing antioxidant power (FRAP), ferrous $\left(\mathrm{Fe}^{2+}\right)$ metal ion chelating activity. They have been screened for the antibacterial and antifungal activities.

\section{MATERIALS AND METHODS}

\section{Materials}

All chemicals and solvents were of commercial reagent grade and used as received from Sigma Aldrich and Spectrochem Pvt. Ltd. Melting points were determined in open capillaries and are uncorrected. The purity of the compounds was checked by TLC using silica gel-G coated aluminum plates (Merck) and spots were visualized by exposing the dry plates to iodine vapors. The IR $(\mathrm{KBr})$ spectra were recorded on a Perkin-Elmer spectrum one FT-IR spectrometer. The ${ }^{1} \mathrm{H}$ NMR (DMSO- $d_{6}$ ) spectra recorded on a Bruker NMR $(400 \mathrm{MHz})$ and the chemical shifts were expressed in ppm $(\delta$ scale) downfield from TMS. Mass spectral data were recorded by electron impact method on JEOL GCMATE II GC-MS mass spectrometer. Elemental analysis was carried out using Flash EA 1112 series elemental analyzer. All the compounds gave $\mathrm{C}, \mathrm{H}$ and $\mathrm{N}$ analysis within $\pm 0.5 \%$ of the theoretical values.

General procedure for the synthesis of $\mathrm{N}$-(4-acetylphenyl)-2chloroacetamide (2) was prepared by following the literature method [25]

General procedure for the synthesis of $2-(1 H$-benzo[d]imidazole-2ylthio) $N$-(4-acetylphenyl) acetamide, $N$-(4-acetylphenyl)-2-((5methoxy-1H-benzo[d]imidazol-2-yl)thio)acetamide and $N$-(4acetylphenyl)-2-(benzo[d]thiazol-2-ylthio) acetamide (3, 4 and 5) were prepared by following the literature method [25]

$N$-(4-acetylphenyl)-2-chloroacetamide (2) $(0.01 \mathrm{~mol})$ obtained was further reacted with 2-mercatobenzimidazole, 2-mercapto-5-methoxy benzimidazole and 2-mercapto benzothiazole $(0.01 \mathrm{~mol})$. The reaction was stirred for $4 \mathrm{~h}$ at room temperature in the presence of $\mathrm{K}_{2} \mathrm{CO}_{3}(0.02$ $\mathrm{mol})$, and acetone $(20 \mathrm{ml})$ was used as the reaction medium. After the completion of reaction monitored on TLC using Toluene: Acetone (8:2) as mobile phase, the product was poured into water and stirred vigorously for $1 \mathrm{~h}$. The separated precipitate was collected and dried. The product was recrystallized from ethanol.

2-(1H-benzo [d] imidazole-2-ylthio)- $N$-(4-acetyl phenyl) acetamide (3)

Yield 86\% (Ethanol); M. P $210^{\circ} \mathrm{C} ; \mathrm{R}_{\mathrm{f}}=0.57$ (Toluene: Acetone 8:2 v/v) IR (KBr) $\left(\lambda_{\max }\right.$ in $\left.\mathrm{cm}^{-1}\right): 1409,1650,2850,3110,3285,3400 .{ }^{1} \mathrm{H}$ 
NMR (DMSO- $\left.\mathrm{d}_{6}+\mathrm{CDCl}_{3}\right)^{\delta}(\mathrm{ppm}): 2.50\left(\mathrm{~S}, 3 \mathrm{H},-\mathrm{CH}_{3}\right), 4.32\left(\mathrm{~S}, 2 \mathrm{H},-\mathrm{CH}_{2}\right)$, 7.10-7.96 (m, 8H, Ar-H), 10.85 (S, 1H,-NH), 12.86 (S, 1H, benzimidazole-NH). Analysis: Calcd for $\mathrm{C}_{17} \mathrm{H}_{15} \mathrm{~N}_{3} \mathrm{O}_{2} \mathrm{~S}$ (325): C, 62.75; H, 4.65; N, 12.91. Found: C, 62.74; H, 4.67; N, 12.90 .

\section{$N$-(4-acetylphenyl)-2-((5-methoxy-1H-benzo[d]imidazol-2-yl) thio)acetamide (4)}

Yield $80 \%$ (Ethanol); M. P $152{ }^{\circ} \mathrm{C} ; \mathrm{R}_{\mathrm{f}}=0.69$ (Toluene: Acetone 8:2 v/v) IR (KBr) $\left(\lambda_{\max }\right.$ in $\left.\mathrm{cm}^{-1}\right): 1406,1625,2862,2992,3285,3379 .{ }^{1} \mathrm{H}$ NMR (DMSO- $\left.\mathrm{d}_{6}+\mathrm{CDCl}_{3}\right)^{8}(\mathrm{ppm}): 2.50\left(\mathrm{~S}, 3 \mathrm{H},-\mathrm{CH}_{3}\right), 3.76\left(\mathrm{~S}, 3 \mathrm{H}, \mathrm{OCH}_{3}\right)$, 4.32 (S, 2H,- $\mathrm{CH}_{2}$ ), 6.72-8.22 (m, 7H, Ar-H), 10.88 (S, 1H,-NH), 12.48 (S, $1 \mathrm{H}$, benzimidazole-NH). Analysis: Calcd for $\mathrm{C}_{18} \mathrm{H}_{17} \mathrm{~N}_{3} \mathrm{O}_{3} \mathrm{~S}$ (355): C, $60.83 ; \mathrm{H}, 4.82 ; \mathrm{N}, 11.82$. Found: C, 60.81; H, 4.85; $\mathrm{N}, 11.81$.

\section{$\mathbf{N}$-(4-acetylphenyl)-2-(benzo[d]thiazol-2-ylthio)acetamide (5)}

Yield 77\% (Ethanol); M. P $130{ }^{\circ} \mathrm{C} ; \mathrm{R}_{\mathrm{f}}=0.63$ (Toluene: Acetone 8:2 v/v) IR (KBr) $\left(\lambda_{\max }\right.$ in $\left.\mathrm{cm}^{-1}\right): 1457,1625,2850,2992,3276,3380 .{ }^{1} \mathrm{H}$ NMR (DMSO- $\left.\mathrm{d}_{6}+\mathrm{CDCl}_{3}\right)^{\delta}(\mathrm{ppm}): 2.50\left(\mathrm{~S}, 3 \mathrm{H},-\mathrm{CH}_{3}\right), 4.40\left(\mathrm{~S}, 2 \mathrm{H},-\mathrm{CH}_{2}\right)$, 7.29-7.92 (m, 8H, Ar-H), $10.71(\mathrm{~S}, 1 \mathrm{H},-\mathrm{NH})$. Analysis: Calcd for $\mathrm{C}_{17} \mathrm{H}_{14} \mathrm{~N}_{2} \mathrm{O}_{2} \mathrm{~S}_{2}$ (342): C, 59.63; H, 4.12; N, 8.18. Found: C, 59.61; H, $4.15 ; \mathrm{N}, 8.19$.

General procedure for the synthesis of 2-((1H-benzo [d]imidazol-2-yl)thio)- $N$-(4-(3-(1H-indol-3-yl)acryloyl)phenyl) acetamide (6a-d)

Claisen-Schmidt condensation of an equimolar mixture of 2-(1Hbenzo[d]imidazol-2-ylthio)- $N$-(4-acetylphenyl)acetamide $(0.01 \mathrm{~mol})$ and various 2,5-disubstituted indole-3-carboxaldehydes $(0.01 \mathrm{~mol})$ were refluxed $(3-4 \mathrm{~h})$ in ethanol $(15-20 \mathrm{ml})$ in the presence of piperidine. The completion of the reaction was monitored by TLC. The product was poured in ice-cold water, and acetic acid was added to that solution. The product obtained was filtered and purified by ethanol.

\section{2-((1H-benzo[d]imidazol-2-yl)thio)- $\mathrm{N}$-(4-(3-(1H-indol-3- yl)acryloyl)phenyl)acetamide (6a)}

Yield $80 \%$ (Ethanol); M. P $218{ }^{\circ} \mathrm{C} ; \mathrm{R}_{\mathrm{f}}=0.57$ (ethyl acetate/hexane $7: 3 \mathrm{v} / \mathrm{v})$ IR (KBr) $\left(\lambda_{\max }\right.$ in $\left.\mathrm{cm}^{-1}\right): 1426,1646,1691,2849,3059,3220$, 3390, 3523; ${ }^{1} \mathrm{H}$ NMR (DMSO-d ${ }_{6}+\mathrm{CDCl}_{3}{ }^{8}(\mathrm{ppm}): 4.32\left(\mathrm{~S}, 2 \mathrm{H},-\mathrm{CH}_{2}\right)$, 7.31-8.13 (m, 13H, 11Ar-H, $\mathrm{CH}=\mathrm{CH}), 9.56(\mathrm{~S}, 1 \mathrm{H}$, indole- $\mathrm{NH}), 10.95$ (S, 1H,-NH), $11.93\left(\mathrm{~S}, 1 \mathrm{H}\right.$, benzimidazole-NH). MS: $\mathrm{m} / \mathrm{z}=452[\mathrm{M}]^{+}$. Analysis: Calcd for $\mathrm{C}_{26} \mathrm{H}_{20} \mathrm{~N}_{4} \mathrm{O}_{2} \mathrm{~S}$ (452): C, 69.01; H, 4.45; N, 12.38 . Found: C, 68.98; H, 4.48; N, 12.37 .

\section{2-((1H-benzo[d]imidazol-2-yl)thio)- $N$-(4-(3-(5-chloro-2-} phenyl-1H-indol-3-yl)acryloyl) phenyl)acetamide (6b)

Yield 85\% (Ethanol); M. P $190{ }^{\circ} \mathrm{C} ; \mathrm{R}_{\mathrm{f}}=0.62$ (ethyl acetate/hexane $7: 3 \mathrm{v} / \mathrm{v}) \mathrm{IR}(\mathrm{KBr})\left(\lambda_{\max }\right.$ in cm$\left.^{-1}\right): 1462,1625,1706,2885,2981,3106$, 3393, 3442, 762. ${ }^{1} \mathrm{H}$ NMR (DMSO- $\left.\mathrm{d}_{6}+\mathrm{CDCl}_{3}\right){ }^{\delta}(\mathrm{ppm}): 4.31$ (S, 2H,$\left.\mathrm{CH}_{2}\right), 7.12-8.35(\mathrm{~m}, 18 \mathrm{H}, 16 \mathrm{Ar}-\mathrm{H}, \mathrm{CH}=\mathrm{CH}), 10.21$ (S, 1H, indole- $\left.\mathrm{NH}\right)$, $11.85(\mathrm{~S}, 1 \mathrm{H},-\mathrm{NH}), 12.39$ (S, 1H, benzimidazole-NH). MS: $\mathrm{m} / \mathrm{z}=562$ $[\mathrm{M}]^{+}, 564[\mathrm{M}+2]^{+}(3: 1)$. Analysis: Calcd for $\mathrm{C}_{32} \mathrm{H}_{23} \mathrm{ClN}_{4} \mathrm{O}_{2} \mathrm{~S}$ (562): C, 68.26; H, 4.12; N, 9.95. Found: C, 68.27; H, 4.09; N, 9.96.

\section{2-((1H-benzo[d]imidazol-2-yl)thio)- $N$-(4-(3-(5-methyl-2- phenyl-1H-indol-3-yl)acryloyl)phenyl)acetamide (6c)}

Yield 77\% (Ethanol); M. P $190{ }^{\circ} \mathrm{C} ; \mathrm{R}_{\mathrm{f}}=0.69$ (ethyl acetate/hexane $7: 3 \mathrm{v} / \mathrm{v}) \mathrm{IR}(\mathrm{KBr})\left(\lambda_{\max }\right.$ in $\left.\mathrm{cm}^{-1}\right): 1463,1626,1725,2842,3028,3250$, 3299, 3421. ${ }^{1} \mathrm{H}$ NMR (DMSO-d $6+\mathrm{CDCl}_{3}{ }^{\delta}(\mathrm{ppm}): 2.41\left(\mathrm{~S}, 3 \mathrm{H},-\mathrm{CH}_{3}\right)$, $4.31\left(\mathrm{~S}, 2 \mathrm{H},-\mathrm{CH}_{2}\right), 7.11-8.03(\mathrm{~m}, 18 \mathrm{H}, 16 \mathrm{Ar}-\mathrm{H}, \mathrm{CH}=\mathrm{CH}), 9.93(\mathrm{~S}, 1 \mathrm{H}$, indole-NH), 10.85 (S, 1H,-NH), 12.28 (S, 1H, benzimidazole-NH). MS: $\mathrm{m} / \mathrm{z}=542[\mathrm{M}]^{+}$. Analysis: Calcd for $\mathrm{C}_{32} \mathrm{H}_{26} \mathrm{~N}_{4} \mathrm{O}_{2} \mathrm{~S}$ (542): C, 73.04; $\mathrm{H}$, 4.83; N, 10.32. Found: $\mathrm{C}, 73.05 ; \mathrm{H}, 4.85 ; \mathrm{N}, 10.31$.

\section{2-((1H-benzo[d]imidazol-2-yl)thio)- $\mathrm{N}$-(4-(3-(5-bromo-1H- indol-3-yl)acryloyl)phenyl) acetamide (6d)}

Yield 73\% (Ethanol); M. P $218{ }^{\circ} \mathrm{C} ; \mathrm{R}_{\mathrm{f}}=0.71$ (ethyl acetate/hexane $7: 3 \mathrm{v} / \mathrm{v})$ IR $(\mathrm{KBr})\left(\lambda_{\max }\right.$ in $\left.\mathrm{cm}^{-1}\right): 1484,1647,1705,2841,3117,3238$, 3381, 3470, 733. ${ }^{1} \mathrm{H}$ NMR (DMSO-d $\left.{ }_{6}+\mathrm{CDCl}_{3}\right){ }^{8}(\mathrm{ppm}): 4.31$ (S, $2 \mathrm{H},-$ $\left.\mathrm{CH}_{2}\right), 7.11-8.33(\mathrm{~m}, 14 \mathrm{H}, 12 \mathrm{Ar}-\mathrm{H}, \mathrm{CH}=\mathrm{CH}), 9.92(\mathrm{~S}, 1 \mathrm{H}$, indole- $\mathrm{NH})$, $10.85(\mathrm{~S}, 1 \mathrm{H},-\mathrm{NH}), 12.31(\mathrm{~S}, 1 \mathrm{H}$, benzimidazole-NH). MS: $\mathrm{m} / \mathrm{z}=530$ $[\mathrm{M}]^{+}, 532[\mathrm{M}+2]^{+}(1: 1)$. Analysis: Calcd for $\mathrm{C}_{26} \mathrm{H}_{19} \mathrm{BrN}_{4} \mathrm{O}_{2} \mathrm{~S}$ (530): $\mathrm{C}$, 58.76; H, 3.60; N, 10.54; Found: C, 58.74; H, 3.58; N, 10.55 .
General procedure for the synthesis of $N$-(4-(3-(1H-indol-3-yl) acryloyl)phenyl)-2-((5-methoxy-1H-benzo[d]imidazol-2-yl) thio)acetamide (7a-d)

Claisen-Schmidt condensation of an equimolar mixture of $\mathrm{N}$-(4acetyl phenyl)-2-((5-methoxy-1H-benzo[d]imidazol-2-yl) thio) acetamide $(0.01 \mathrm{~mol})$ and various 2, 5-disubstituted indole-3carboxaldehyde $(0.01 \mathrm{~mol})$ were refluxed $(3-4 \mathrm{~h})$ in ethanol (15-20 $\mathrm{ml}$ ) in the presence of piperidine. The completion of the reaction was monitored by TLC. The product was poured in ice-cold water, and acetic acid was added to that solution. The product obtained was filtered and purified by ethanol.

$N$-(4-(3-(1H-indol-3-yl)acryloyl)phenyl)-2-((5-methoxy-1Hbenzo[d]imidazol-2-yl)thio) acetamide (7a)

Yield 75\% (Ethanol); M. P $95^{\circ} \mathrm{C} ; \mathrm{R}_{\mathrm{f}}=0.54$ (ethyl acetate/hexane 7:3 v/v) IR $(\mathrm{KBr})\left(\lambda_{\max }\right.$ in $\left.\mathrm{cm}^{-1}\right): 1426,1677,1706,2849,2981,3271$, 3380, 3410. ${ }^{1} \mathrm{H}$ NMR (DMSO-d $\left.6+\mathrm{CDCl}_{3}\right){ }^{\delta}(\mathrm{ppm}): 3.98\left(\mathrm{~S}, 3 \mathrm{H},-\mathrm{OCH}_{3}\right.$, $4.44\left(\mathrm{~S}, 2 \mathrm{H},-\mathrm{CH}_{2}\right), 7.19-8.09(\mathrm{~m}, 14 \mathrm{H}, 12 \mathrm{Ar}-\mathrm{H}, \mathrm{CH}=\mathrm{CH}), 9.98(\mathrm{~S}, 1 \mathrm{H}$, indole-NH), $10.26(\mathrm{~S}, 1 \mathrm{H},-\mathrm{NH}), 12.26(\mathrm{~S}, 1 \mathrm{H}$, benzimidazole-NH). MS: $\mathrm{m} / \mathrm{z}=482[\mathrm{M}]^{+}$. Analysis: Calcd for $\mathrm{C}_{27} \mathrm{H}_{22} \mathrm{~N}_{4} \mathrm{O}_{3} \mathrm{~S}$ (482): $\mathrm{C}, 67.20 ; \mathrm{H}$, $4.60 ; \mathrm{N}, 11.61$. Found: C, 67.21; H, 4.62; N, 11.60 .

$\mathrm{N}$-(4-(3-(5-chloro-2-phenyl-1H-indol-3-yl)acryloyl)phenyl)-2((5-methoxy-1H-benzo[d]imidazol-2-yl)thio)acetamide (7b)

Yield 86\% (Ethanol); M. P $200{ }^{\circ} \mathrm{C} ; \mathrm{R}_{\mathrm{f}}=0.58$ (ethyl acetate/hexane 7:3 v/v) IR (KBr) $\left(\lambda_{\max }\right.$ in $\left.\mathrm{cm}^{-1}\right): 1426,1646,1725,2888,3040,3100,3326$, 3442, 795. ${ }^{1} \mathrm{H}$ NMR (DMSO-d $\left.6+\mathrm{CDCl}_{3}\right)^{\delta}(\mathrm{ppm}): 3.38\left(\mathrm{~S}, 3 \mathrm{H},-\mathrm{OCH}_{3}\right), 4.42$ $\left(\mathrm{S}, 2 \mathrm{H},-\mathrm{CH}_{2}\right), 7.11-8.01(\mathrm{~m}, 14 \mathrm{H}, 12 \mathrm{Ar}-\mathrm{H}, \mathrm{CH}=\mathrm{CH}), 9.92(\mathrm{~S}, 1 \mathrm{H}$, indole$\mathrm{NH}), 10.76(\mathrm{~S}, 1 \mathrm{H},-\mathrm{NH}), 12.27$ (S, 1H, benzimidazole-NH). MS: $\mathrm{m} / \mathrm{z}=$ $592[\mathrm{M}]^{+}, 594[\mathrm{M}+2]^{+}(3: 1)$. Analysis: Calcd for $\mathrm{C}_{33} \mathrm{H}_{25} \mathrm{ClN}_{4} \mathrm{O}_{3} \mathrm{~S}$ (592): C, $66.83 ; \mathrm{H}, 4.25 ; \mathrm{N}, 9.45$. Found: $\mathrm{C}, 66.85 ; \mathrm{H}, 4.23 ; \mathrm{N}, 9.43$.

2-((5-methoxy-1H-benzo[d]imidazol-2-yl)thio)- $\mathrm{N}$-(4-(3-(5methyl-2-phenyl-1H-indol-3-yl)acryloyl)phenyl)acetamide (7c)

Yield $94 \%$ (Ethanol); M. P $215{ }^{\circ} \mathrm{C} ; \mathrm{R}_{\mathrm{f}}=0.55$ (ethyl acetate/hexane $7: 3 \mathrm{v} / \mathrm{v}) \operatorname{IR}(\mathrm{KBr})\left(\lambda_{\max }\right.$ in $\left.\mathrm{cm}^{-1}\right): 1478,1677,1741,2840,2897,3261$, 3371, 3428. ${ }^{1} \mathrm{H}$ NMR (DMSO-d $\left.{ }_{6}+\mathrm{CDCl}_{3}\right){ }^{8}(\mathrm{ppm}): 3.17\left(\mathrm{~S}, 3 \mathrm{H},-\mathrm{CH}_{3}\right)$, $3.97\left(\mathrm{~S}, 3 \mathrm{H},-\mathrm{OCH}_{3}\right), 4.44\left(\mathrm{~S}, 2 \mathrm{H},-\mathrm{CH}_{2}\right), 7.35-8.81(\mathrm{~m}, 17 \mathrm{H}, 15 \mathrm{Ar}-\mathrm{H}$ $\mathrm{CH}=\mathrm{CH}), 9.94(\mathrm{~S}, 1 \mathrm{H}$, indole- $\mathrm{NH}), 10.78(\mathrm{~S}, 1 \mathrm{H},-\mathrm{NH}), 12.17(\mathrm{~S}, 1 \mathrm{H}$, benzimidazole-NH). MS: $\mathrm{m} / \mathrm{z}=572[\mathrm{M}]^{+}$. Analysis: Calcd for $\mathrm{C}_{34} \mathrm{H}_{28} \mathrm{~N}_{4} \mathrm{O}_{3} \mathrm{~S}$ (572): C, 71.31; H, 4.93; N, 9.78. Found: C, 71.35; H, $4.91 ; \mathrm{N}, 9.79$.

$\mathrm{N}$-(4-(3-(5-bromo-1H-indol-3-yl)acryloyl)phenyl)-2-((5methoxy-1H-benzo[d]imidazol-2-yl)thio)acetamide (7d)

Yield 74\% (Ethanol); M. P $165^{\circ} \mathrm{C} ; \mathrm{R}_{\mathrm{f}}=0.59$ (ethyl acetate/hexane $7: 3 \mathrm{v} / \mathrm{v}) \mathrm{IR}(\mathrm{KBr})\left(\lambda_{\max }\right.$ in $\left.\mathrm{cm}^{-1}\right): 1425,1677,1741,2831,2983,3115$, 3371, 3456, 768. ${ }^{1} \mathrm{H}$ NMR (DMSO-d $\left.6+\mathrm{CDCl}_{3}\right){ }^{8}(\mathrm{ppm}): 3.87(\mathrm{~S}, 3 \mathrm{H},-$ $\left.\mathrm{OCH}_{3}\right), 4.48\left(\mathrm{~S}, 2 \mathrm{H},-\mathrm{CH}_{2}\right), 7.12-8.05(\mathrm{~m}, 13 \mathrm{H}, 11 \mathrm{Ar}-\mathrm{H}, \mathrm{CH}=\mathrm{CH}), 10.12$ $(\mathrm{S}, 1 \mathrm{H}$, indole- $\mathrm{NH}), 11.16(\mathrm{~S}, 1 \mathrm{H},-\mathrm{NH}), 12.37 \mathrm{~S}, 1 \mathrm{H}$, benzimidazoleNH). MS: $\mathrm{m} / \mathrm{z}=560[\mathrm{M}]^{+}, 562[\mathrm{M}+2]^{+}(1: 1)$. Analysis: Calcd for $\mathrm{C}_{27} \mathrm{H}_{21} \mathrm{BrN}_{4} \mathrm{O}_{3} \mathrm{~S}$ (560): C, 57.76; $\mathrm{H}, 3.77 ; \mathrm{N}, 9.98$. Found: $\mathrm{C}, 57.80 ; \mathrm{H}$, 3.78; N, 9.99 .

General Procedure for the synthesis of $\mathrm{N}$ - $(4-(3-(1 \mathrm{H}$-indol-3yl)acryloyl)phenyl)-2-(benzo[d]thiazol-2-ylthio)acetamide (8a-d)

Claisen-Schmidt condensation of an equimolar mixture of $\mathrm{N}$-(4acetylphenyl)-2-(benzo[d]thiazol-2-ylthio)acetamide $(0.01 \mathrm{~mol})$ and various 2,5-disubstituted indole-3-carboxaldehydes $(0.01 \mathrm{~mol})$ were refluxed (3-4 h) in ethanol $(15-20 \mathrm{ml})$ in the presence of piperidine. The completion of the reaction was monitored by TLC. The product was poured in ice-cold water, and acetic acid was added to that solution. The product obtained was filtered and purified by ethanol.

$N$-(4-(3-(1H-indol-3-yl)acryloyl)phenyl)-2-(benzo[d]thiazol-2ylthio)acetamide (8a)

Yield 80\% (Ethanol); M. P $150{ }^{\circ} \mathrm{C} ; \mathrm{R}_{\mathrm{f}}=0.57$ (ethyl acetate/hexane $7: 3 \mathrm{v} / \mathrm{v})$ IR $(\mathrm{KBr})\left(\lambda_{\max }\right.$ in cm $\left.\mathrm{cm}^{-1}\right): 1463,1647,1707,2862,2961,3191$, 3390. ${ }^{1} \mathrm{H}$ NMR (DMSO- $\left.\mathrm{d}_{6}+\mathrm{CDCl}_{3}\right)^{8}(\mathrm{ppm}): 4.31\left(\mathrm{~S}, 2 \mathrm{H},-\mathrm{CH}_{2}\right), 7.20-7.99$ (m, 14H, 12Ar-H, CH=CH), 9.95 (S, 1H, indole-NH), 10.88 (S, 1H,-NH). MS: $\mathrm{m} / \mathrm{z}=469[\mathrm{M}]^{+}$. Analysis: Calcd for $\mathrm{C}_{26} \mathrm{H}_{19} \mathrm{~N}_{3} \mathrm{O}_{2} \mathrm{~S}_{2}$ (469): C, 66.50; H, 4.08; N, 8.95. Found: C, 66.54; H, 4.07; N, 8.93. 
2-(benzo[d] thiazol-2-ylthio)- $\mathrm{N}$-(4-(3-(5-chloro-2-phenyl- $1 \mathrm{H}$ indol-3-yl)acryloyl)phenyl) acetamide (8b)

Yield 92\% (Ethanol); M. P $220{ }^{\circ} \mathrm{C} ; \mathrm{R}_{\mathrm{f}}=0.59$ (ethyl acetate/hexane $7: 3 \mathrm{v} / \mathrm{v}) \mathrm{IR}(\mathrm{KBr})\left(\lambda_{\max }\right.$ in cm $\left.\mathrm{cm}^{-1}\right): 1453,1624,1741,2885,2977,3251$, 3362, 753. ${ }^{1} \mathrm{H}$ NMR (DMSO- $\left.\mathrm{d}_{6}+\mathrm{CDCl}_{3}\right){ }^{8}(\mathrm{ppm}): 4.33\left(\mathrm{~S}, 2 \mathrm{H},-\mathrm{CH}_{2}\right)$, 7.36-8.19 (m, 18H, 16Ar-H, CH=CH), 10.5 (S, 1H, indole- $\mathrm{NH}), 11.79$ (S, $1 \mathrm{H},-\mathrm{NH})$. MS: $\mathrm{m} / \mathrm{z}=579[\mathrm{M}]^{+}, 581[\mathrm{M}+2]^{+}(3: 1)$. Analysis: Calcd for $\mathrm{C}_{32} \mathrm{H}_{22} \mathrm{ClN}_{3} \mathrm{O}_{2} \mathrm{~S}_{2}$ (579): C, 66.25; H, 3.82; N, 7.24. Found: C, 66.28; H, $3.81 ; \mathrm{N}, 7.25$.

2-(benzo[d] thiazol-2-ylthio)- $\mathrm{N}$-(4-(3-(5-methyl-2-phenyl-1Hindol-3-yl)acryloyl)phenyl) acetamide (8c)

Yield 84\% (Ethanol); M. P $155^{\circ} \mathrm{C} ; \mathrm{R}_{\mathrm{f}}=0.7$ (ethyl acetate/hexane 7:3 v/v) IR (KBr) $\left(\lambda_{\max }\right.$ in $\left.\mathrm{cm}^{-1}\right): 1461,1648,1725,2873,2997,3225$,
3378. ${ }^{1} \mathrm{H}$ NMR (DMSO- $\left.\mathrm{d}_{6}+\mathrm{CDCl}_{3}\right)^{\delta}(\mathrm{ppm}): 2.40\left(\mathrm{~S}, 3 \mathrm{H},-\mathrm{CH}_{3}\right), 4.32(\mathrm{~S}$, $\left.2 \mathrm{H},-\mathrm{CH}_{2}\right), 7.21-7.82(\mathrm{~m}, 18 \mathrm{H}, 16 \mathrm{Ar}-\mathrm{H}, \mathrm{CH}=\mathrm{CH}), 9.88(\mathrm{~S}, 1 \mathrm{H}$, indole$\mathrm{NH}), 11.37(\mathrm{~S}, 1 \mathrm{H},-\mathrm{NH})$. MS: $\mathrm{m} / \mathrm{z}=559[\mathrm{M}]^{+}$. Analysis: Calcd for $\mathrm{C}_{33} \mathrm{H}_{25} \mathrm{~N}_{3} \mathrm{O}_{2} \mathrm{~S}_{2}$ (559): C, 70.82; $\mathrm{H}, 4.50 ; \mathrm{N}, 7.51$. Found: $\mathrm{C}, 70.85 ; \mathrm{H}$, $4.49 ; \mathrm{N}, 7.53$

2-(benzo[d]thiazol-2-ylthio)- $N$-(4-(3-(5-bromo-1H-indol-3yl)acryloyl)phenyl)acetamide (8d)

Yield 75\% (Ethanol); M. P $230{ }^{\circ} \mathrm{C} ; \mathrm{R}_{\mathrm{f}}=0.72$ (ethyl acetate/hexane $7: 3 \mathrm{v} / \mathrm{v}) \mathrm{IR}(\mathrm{KBr})\left(\lambda_{\max }\right.$ in $\left.\mathrm{cm}^{-1}\right): 1432,1644,1761,2843,2917,3213$, 3320, 749. ${ }^{1} \mathrm{H}$ NMR (DMSO- $\mathrm{d}_{6}+\mathrm{CDCl}_{3}{ }^{8}(\mathrm{ppm}): 4.30\left(\mathrm{~S}, 2 \mathrm{H},-\mathrm{CH}_{2}\right)$, 7.36-8.19 (m, 14H, 12Ar-H, CH=CH), 10.21 (S, 1H, indole-NH), 11.52 $(\mathrm{S}, 1 \mathrm{H},-\mathrm{NH}) . \mathrm{MS}: \mathrm{m} / \mathrm{z}=547[\mathrm{M}]^{+}, 549[\mathrm{M}+2]^{+}(1: 1)$. Analysis: Calcd for $\mathrm{C}_{26} \mathrm{H}_{18} \mathrm{BrN}_{3} \mathrm{O}_{2} \mathrm{~S}_{2}$ (547): C, 56.94; $\mathrm{H}, 3.31$; N, 7.66. Found: C, 56.97; H, $3.30 ; \mathrm{N}, 7.68$.

Table 1: Physical constant of all the synthesized compounds 3, 4, 5 and 6-8 (a-d)

\begin{tabular}{|c|c|c|c|c|c|c|}
\hline S. No. & Sample code & $\mathbf{R}$ & $\mathbf{R}^{\mathbf{1}}$ & M. For. & M. Wt. & M. Pt. ${ }^{\circ} \mathrm{C}$ \\
\hline 1 & 3 & - & - & $\mathrm{C}_{17} \mathrm{H}_{15} \mathrm{~N}_{3} \mathrm{O}_{2} \mathrm{~S}$ & 325 & 210 \\
\hline 2 & 4 & - & - & $\mathrm{C}_{18} \mathrm{H}_{17} \mathrm{~N}_{3} \mathrm{O}_{3} \mathrm{~S}$ & 355 & 152 \\
\hline 3 & 5 & - & - & $\mathrm{C}_{17} \mathrm{H}_{14} \mathrm{~N}_{2} \mathrm{O}_{2} \mathrm{~S}_{2}$ & 342 & 130 \\
\hline 4 & $6 a$ & $\mathrm{H}$ & $\mathrm{H}$ & $\mathrm{C}_{26} \mathrm{H}_{20} \mathrm{~N}_{4} \mathrm{O}_{2} \mathrm{~S}$ & 452 & 218 \\
\hline 5 & $6 b$ & $\mathrm{Ph}$ & $\mathrm{Cl}$ & $\mathrm{C}_{32} \mathrm{H}_{23} \mathrm{ClN}_{4} \mathrm{O}_{2} \mathrm{~S}$ & 562 & 190 \\
\hline 6 & $6 c$ & $\mathrm{Ph}$ & $\mathrm{CH}_{3}$ & $\mathrm{C}_{32} \mathrm{H}_{26} \mathrm{~N}_{4} \mathrm{O}_{2} \mathrm{~S}$ & 542 & 190 \\
\hline 7 & $6 \mathrm{~d}$ & $\mathrm{H}$ & $\mathrm{Br}$ & $\mathrm{C}_{26} \mathrm{H}_{19} \mathrm{BrN}_{4} \mathrm{O}_{2} \mathrm{~S}$ & 530 & 218 \\
\hline 8 & $7 a$ & $\mathrm{H}$ & $\mathrm{H}$ & $\mathrm{C}_{27} \mathrm{H}_{22} \mathrm{~N}_{4} \mathrm{O}_{3} \mathrm{~S}$ & 482 & 95 \\
\hline 9 & $7 \mathrm{~b}$ & $\mathrm{Ph}$ & $\mathrm{Cl}$ & $\mathrm{C}_{33} \mathrm{H}_{25} \mathrm{ClN}_{4} \mathrm{O}_{3} \mathrm{~S}$ & 592 & 200 \\
\hline 10 & $7 c$ & $\mathrm{Ph}$ & $\mathrm{CH}_{3}$ & $\mathrm{C}_{34} \mathrm{H}_{28} \mathrm{~N}_{4} \mathrm{O}_{3} \mathrm{~S}$ & 572 & 215 \\
\hline 11 & $7 d$ & $\mathrm{H}$ & $\mathrm{Br}$ & $\mathrm{C}_{27} \mathrm{H}_{21} \mathrm{BrN}_{4} \mathrm{O}_{3} \mathrm{~S}$ & 560 & 165 \\
\hline 12 & $8 a$ & $\mathrm{H}$ & $\mathrm{H}$ & $\mathrm{C}_{26} \mathrm{H}_{19} \mathrm{~N}_{3} \mathrm{O}_{2} \mathrm{~S}_{2}$ & 469 & 150 \\
\hline 13 & $8 b$ & $\mathrm{Ph}$ & $\mathrm{Cl}$ & $\mathrm{C}_{32} \mathrm{H}_{22} \mathrm{ClN}_{3} \mathrm{O}_{2} \mathrm{~S}_{2}$ & 579 & 220 \\
\hline 14 & $8 c$ & $\mathrm{Ph}$ & $\mathrm{CH}_{3}$ & $\mathrm{C}_{33} \mathrm{H}_{25} \mathrm{~N}_{3} \mathrm{O}_{2} \mathrm{~S}_{2}$ & 559 & 155 \\
\hline 15 & $8 d$ & $\mathrm{H}$ & $\mathrm{Br}$ & $\mathrm{C}_{26} \mathrm{H}_{18} \mathrm{BrN}_{3} \mathrm{O}_{2} \mathrm{~S}_{2}$ & 547 & 230 \\
\hline
\end{tabular}

M. for.-Molecular formula, M. wt.-Molecular weight, M. pt.-Melting point.

\section{Biological activities}

\section{Antibacterial and antifungal assay}

The newly synthesized compounds were screened against bacterial and fungicidal activities by an agar plate diffusion method and potato dextrose agar (PDA) diffusion method respectively [29]. All the compounds were screened for their antibacterial activity against Escherichia coli (MTCC-723), Staphylococcus aureus (ATCC-29513), and Pseudomonas aeruginosa (MTCC-1688), as well as antifungal activity against Aspergillus niger (MTCC-281), Aspergillus flavus (MTCC-1973), and Aspergillus oryzae (MTCC-3567T). DMSO was used as a vehicle to get the desired concentration of compounds to test upon microbial strains. Streptomycin and fluconazole were used as standards for antibacterial and antifungal activities respectively. The experiment was done in triplicate, and average values were calculated. The results of antibacterial and antifungal are summarized in (table 2 ) and (table 3 ) respectively.

\section{Antioxidant activity assay}

\section{1, 1-Diphenyl-2-picryl hydrazyl (DPPH) radical scavenging activity (RSA)}

The free radical scavenging activity (RSA) of all the compounds at concentrations of $25,50,75$ and $100 \mu \mathrm{g} / \mathrm{ml}$ were carried out in the presence of freshly prepared solution of stable free radical DPPH $(0.04 \% \mathrm{w} / \mathrm{v})$ following Hatano's method[26],using 2-tert-butyl-4methoxyphenol (butylated hydroxy anisole, BHA), 2-(1,1-dimethyl ethyl)-1,4-benzenediol (2-tert-butyl hydroquinone, TBHQ) and ascorbic acid (AA) as standards. All the test analyses were performed on three replicates, and the results were averaged. The results in percentage were expressed as the ratio of absorption decrease of DPPH in the presence of test compounds and absorption of DPPH in the absence of test compounds at $\lambda 517 \mathrm{~nm}$ on ELICO SL $171 \mathrm{Mini}$ Spec, spectrophotometer. The percentage scavenging activity of the DPPH free radical was measured using the following equation:

$$
\% \text { of DPPH RSA }=\frac{\text { Absorbance of Control }- \text { Absorbance of Sample }}{\times 100 \text { Absorbance of Control }}
$$

The results are shown in fig. 1 to 4 .

\section{Ferric ions $\left(\mathrm{Fe}^{3+}\right)$ reducing antioxidant power (FRAP)}

The Ferric ions $\left(\mathrm{Fe}^{3+}\right)$ reducing antioxidant power (FRAP) of the synthesized compounds were determined according to the literature method [27]. Different concentrations of samples (25, $50,75$ and $100 \mu \mathrm{g} / \mathrm{ml})$ in DMSO $(1 \mathrm{ml})$ were mixed with phosphate buffer $(2.5 \mathrm{ml}, 0.2 \mathrm{~mol}, \mathrm{pH}=6.6)$ and potassium ferricyanide $(2.5$ $\mathrm{ml}, 1 \%$ ). The mixture was incubated at $50^{\circ} \mathrm{C}$ for $20 \mathrm{~min}$. After which a portion of trichloroacetic acid $(2.5 \mathrm{ml}, 10 \%)$ was added to the mixture and centrifuged for $10 \mathrm{~min}$, at $1000 \mathrm{Xg}$. The upper layer of solution $(2.5 \mathrm{ml})$ was mixed with distilled water $(2.5 \mathrm{ml})$ and ferric chloride $(0.5 \mathrm{ml}, 0.1 \%)$. Then absorbance at $\lambda 700 \mathrm{~nm}$ was measured in a spectrophotometer. The higher absorbance of the reaction mixture indicated greater reducing power. The results are shown in fig. 5 to 8.

\section{Ferrous $\left(\mathrm{Fe}^{2+}\right)$ metal ion chelating activity}

The chelating activity of ferrous ion of synthesized compounds was estimated by following reported method [28]. The test samples $(25$, $50,75$ and $100 \mu \mathrm{g} / \mathrm{ml})$ in ethanolic solution $(0.4 \mathrm{ml})$ were added to a solution of $\mathrm{FeCl}_{2}(0.05 \mathrm{ml}, 2 \mathrm{mmol})$. The reaction was initiated by the addition of ferrozine $(0.2 \mathrm{ml}, 5 \mathrm{mmol})$ and the total volume was adjusted to $4 \mathrm{ml}$ with ethanol. Ferozine reacted with the divalent iron, form stable magenta complex species that were very soluble in water. The mixture was shaken vigorously and kept at room temperature for $10 \mathrm{~min}$. Then the absorbance of the solution was measured spectrophotometrically at $\lambda 562 \mathrm{~nm}$. All test analyses were run in triplicate and averaged. The percentage of inhibition of the ferrozine $\mathrm{Fe}^{2+}$ complex formation was calculated using the following formula: 
$\%$ of ferrousion chelating

$=\frac{\text { Absorbance of Control }- \text { Absorbance of Sample }}{\text { Absorbance of Control }} \times[10]^{\circ}$

The control contains $\mathrm{FeCl}_{2}$ and ferrozine, complex formation molecule. The results are shown in fig. 9 to 12 .

\section{RESULTS AND DISCUSSION}

\section{Chemistry}

In the present investigation, 4-aminoacetophenone (1) was reacted with chloroacetylchloride to form an intermediate $\mathrm{N}$-(4-acetylphenyl)-2chloroacetamide (2), which on reaction with 2-mercatobenzimidazole, 2-mercapto-5-methoxy benzimidazole and 2-mercapto benzothiazole, resulted in the formation of 2-(1H-benzo[d]imidazole-2-ylthio) $N$-(4acetylphenyl)acetamide (3), $\quad \mathrm{N}$-(4-acetylphenyl)-2-((5-methoxy- $1 \mathrm{H}$ benzo[d]imidazol-2-yl)thio)acetamide (4) and $\mathrm{N}$-(4-acetylphenyl)-2(benzo[d]thiazol-2-ylthio)acetamide (5) respectively by following the literature method [25].

Compound 3, 4 and 5 on Claisen-Schmidt condensation with various 2,5-disubstituted indole-3-carboxaldehydes were refluxed in ethanol in the presence of piperidine to yield the products $2-((1 H-$ benzo[d]imidazol-2-yl)thio)- $N$-(4-(3-(1H-indol-3-yl)acryloyl) phenyl)acetamide $6 \mathrm{a}-\mathrm{d}, \mathrm{N}$-(4-(3-(1H-indol-3-yl)acryloyl) phenyl)-2((5-methoxy-1H-benzo[d]imidazol-2-yl)thio)acetamide 7a-d and $\mathrm{N}$ (4-(3-(1H-indol-3-yl)acryloyl)phenyl)-2-(benzo [d] thiazol-2-ylthio) acetamide $8 \mathrm{a}-\mathrm{d}$ respectively as presented in scheme-1.

The physical data of the compounds were presented in table-1. The structures of the compounds were confirmed by IR, ${ }^{1} \mathrm{H}$ NMR, mass spectral studies and elemental data. The IR spectrum of 6 a exhibited absorption band at $3523 \mathrm{~cm}^{-1}, 3390 \mathrm{~cm}^{-1}$ and $3220 \mathrm{~cm}^{-1}$ for $\mathrm{NH}$ stretching frequency of indole, benzimidazole and amide respectively. The absorption band at $1691 \mathrm{~cm}^{-1}$ and $1646 \mathrm{~cm}^{-}$ ${ }^{1}$ corresponds to $\mathrm{C}=0$ stretching of carbonyl and amide. In the ${ }^{1} \mathrm{HNMR}$ spectrum, the compound 6 a showed a singlet peaks at $11.93,10.95$ and $9.56 \mathrm{ppm}$ ascribed to $\mathrm{NH}$ protons of benzimidazole, amide and indole respectively.

In addition to this, eleven aromatic protons and two protons of $\mathrm{CH}=\mathrm{CH}$ resonated as a multiplet in the region $7.31-8.13 \mathrm{ppm}$. The singlet at $4.32 \mathrm{ppm}$ is due to the two protons of a methylene group. Further, the mass spectrum of 6 a showed a molecular ion peak $\mathrm{M}^{+}$at $\mathrm{m} / \mathrm{z} 452$, which confirms its molecular weight and is in good agreement with nitrogen rule.

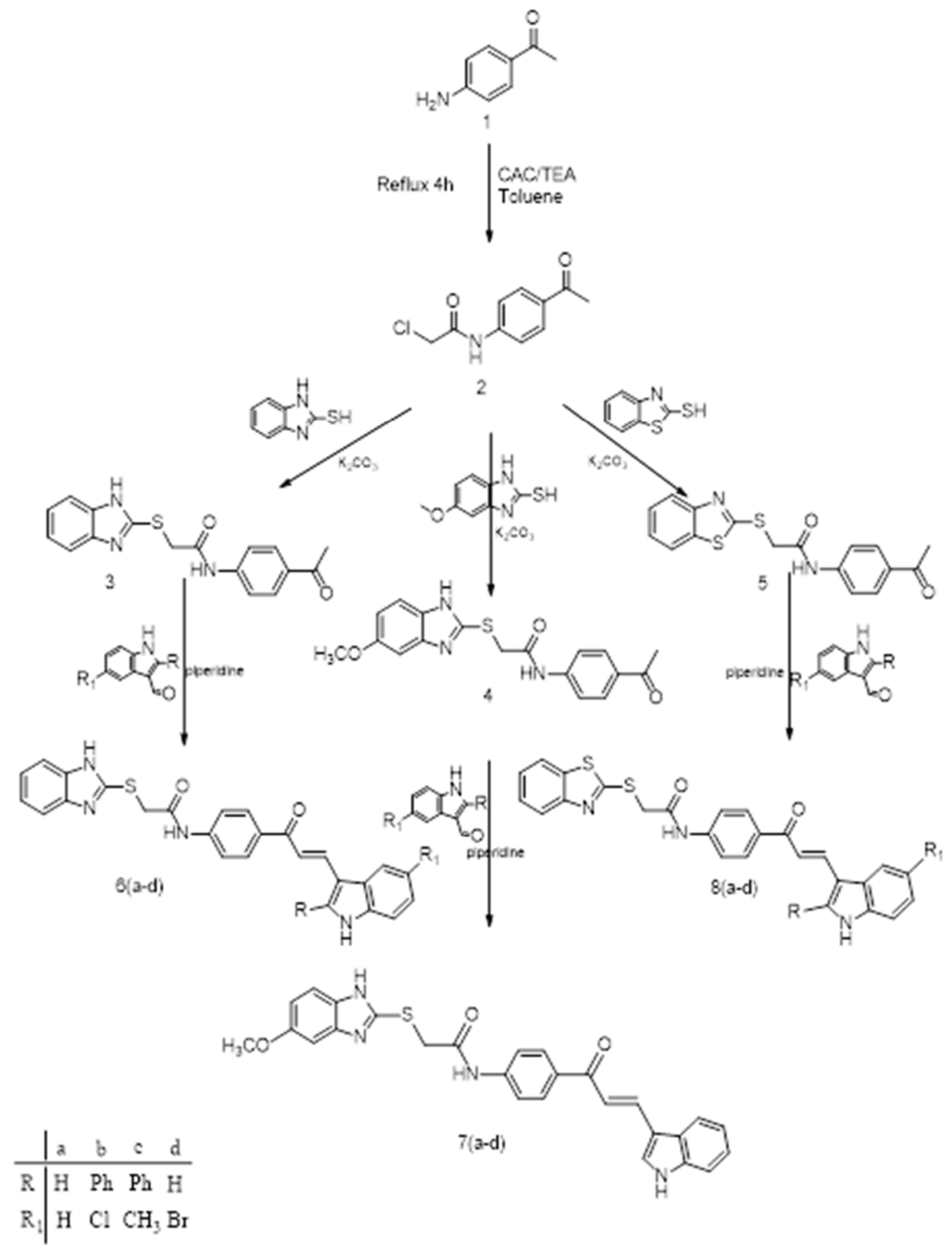

Scheme 1: Synthesis of compounds 3, 4, 5 and 6-8 (a-d) 
Table 2: Antibacterial activity, size of inhibition zone $(\mathrm{mm})$ formed at different concentrations $(1000,500,250$ and $125 \mu \mathrm{g} / \mathrm{ml})$ of synthesized compounds $3,4,5$ and $6-8$ (a-d)

\begin{tabular}{|c|c|c|c|c|c|c|c|c|c|c|c|c|}
\hline \multirow{3}{*}{$\begin{array}{l}\text { Compou } \\
\text { nd }\end{array}$} & \multicolumn{12}{|c|}{ Zone of inhibition in $\mathrm{mm}$} \\
\hline & \multicolumn{4}{|c|}{ Staphylococcus aureus } & \multicolumn{4}{|c|}{ Escherichia coli } & \multicolumn{4}{|c|}{ Pseudomonas aeruginosa } \\
\hline & 1000 & 500 & 250 & 125 & 1000 & 500 & 250 & 125 & 1000 & 500 & 250 & 125 \\
\hline \multirow[t]{2}{*}{3} & $9.33 \pm 0$ & $8.66 \pm 0$ & $8.00 \pm 0$ & $7.66 \pm 0$ & $10.33 \pm 0$ & $11.66 \pm 0$ & $9.66 \pm 0$ & $7.66 \pm 0$ & $8 \pm 0.81$ & $07.33 \pm 0$ & $07.33 \pm 0$ & $07.33 \pm 0$ \\
\hline & 47 & 47 & 81 & 94 & .47 & .94 & 47 & 47 & & .47 & .47 & .94 \\
\hline \multirow[t]{2}{*}{4} & $10.33 \pm 0$ & $8.66 \pm 0$ & $10.66 \pm 0$ & $10.33 \pm 0$ & $11.33 \pm 1$ & $10.33 \pm 0$ & $10.66 \pm 0$ & $9.33 \pm 0$ & $10.33 \pm 1$ & $10.66 \pm 1$ & $10.66 \pm 0$ & $9.33 \pm 0$ \\
\hline & .47 & 47 & .47 & .47 & .24 & .47 & .47 & 47 & .24 & .24 & .47 & 47 \\
\hline \multirow[t]{2}{*}{5} & $10.66 \pm 0$ & $8.00 \pm 0$ & $9.66 \pm 0$ & $7.66 \pm 0$ & $10.33 \pm 0$ & $9.66 \pm 0$ & $7.66 \pm 0$ & $8 \pm 0.81$ & $8.66 \pm 0$ & $8.00 \pm 0$ & $07.33 \pm 0$ & $9.33 \pm 0$ \\
\hline & .47 & 81 & 47 & 94 & .47 & 47 & 47 & & 47 & 81 & .94 & 47 \\
\hline \multirow[t]{2}{*}{$6 a$} & $10.33 \pm 1$ & $10.66 \pm 0$ & $10.66 \pm 0$ & $10.33 \pm 0$ & $11.33 \pm 1$ & $11.66 \pm 0$ & $10.66 \pm 0$ & $9.33 \pm 0$ & $9.33 \pm 0$ & $07.33 \pm 0$ & $9.66 \pm 0$ & $9.66 \pm 0$ \\
\hline & .24 & .47 & .47 & .47 & .24 & .94 & .47 & 47 & 47 & .94 & 47 & 47 \\
\hline \multirow[t]{2}{*}{$6 b$} & $12.33 \pm 0$ & $11.66 \pm 0$ & $12.66 \pm 0$ & $12.66 \pm 0$ & $12.66 \pm 0$ & $12.66 \pm 0$ & $11.66 \pm 0$ & $12 \pm 0.81$ & $12 \pm 0.81$ & $11.66 \pm 0$ & $11.66 \pm 0$ & $12.66 \pm 0$ \\
\hline & .47 & .47 & .47 & .47 & .47 & .47 & .47 & & & .47 & .47 & .47 \\
\hline \multirow[t]{2}{*}{$6 c$} & $12 \pm 0.81$ & $11.66 \pm 0$ & $10.33 \pm 0$ & $9.66 \pm 0$ & $10.66 \pm 0$ & $11.66 \pm 0$ & $11.66 \pm 0$ & $12.33 \pm 0$ & $10.66 \pm 0$ & $12.33 \pm 0$ & $12.33 \pm 0$ & $10.66 \pm 0$ \\
\hline & & .47 & .47 & 47 & .47 & .47 & .47 & .47 & .47 & .47 & .47 & .47 \\
\hline \multirow[t]{2}{*}{$6 d$} & $12.33 \pm 0$ & $13.33 \pm 0$ & $14.33 \pm 0$ & $13.33 \pm 0$ & $12.66 \pm 0$ & $12.66 \pm 0$ & $12.33 \pm 0$ & $13.33 \pm 0$ & $14.33 \pm 0$ & $12.33 \pm 0$ & $13.33 \pm 0$ & $12.33 \pm 0$ \\
\hline & .47 & .94 & .47 & .94 & .47 & .47 & .47 & .94 & .47 & .47 & .94 & .47 \\
\hline \multirow[t]{2}{*}{$7 a$} & $12.33 \pm 0$ & $11.66 \pm 0$ & $10.66 \pm 0$ & $12.33 \pm 0$ & $10.66 \pm 0$ & $11.66 \pm 0$ & $12 \pm 0.81$ & $12.33 \pm 0$ & $10.66 \pm 0$ & $12.66 \pm 0$ & $10.66 \pm 0$ & $11.66 \pm 0$ \\
\hline & .47 & .47 & .47 & .47 & .47 & .47 & & .47 & .47 & .47 & .47 & .47 \\
\hline \multirow[t]{2}{*}{$7 b$} & $12.66 \pm 0$ & $11.66 \pm 0$ & $13.33 \pm 0$ & $13.33 \pm 0$ & $10.66 \pm 0$ & $12.66 \pm 0$ & $12 \pm 0.81$ & $12.66 \pm 0$ & $11.66 \pm 0$ & $12.33 \pm 0$ & $13.33 \pm 0$ & $12.33 \pm 0$ \\
\hline & .47 & .47 & .94 & .94 & .47 & .47 & & .47 & .47 & .47 & .94 & .47 \\
\hline \multirow[t]{2}{*}{ 7c } & $12.33 \pm 0$ & $10.66 \pm 0$ & $10.66 \pm 0$ & $12 \pm 0.81$ & $11.66 \pm 0$ & $10.66 \pm 0$ & $12.33 \pm 0$ & $12.66 \pm 0$ & $11.66 \pm 0$ & $11.66 \pm 0$ & $10.66 \pm 0$ & $10.66 \pm 0$ \\
\hline & .47 & .47 & .47 & & .47 & .47 & .47 & .47 & .47 & .47 & .47 & .47 \\
\hline \multirow[t]{2}{*}{$7 d$} & $14.33 \pm 0$ & $15.33 \pm 0$ & $15.66 \pm 0$ & $15.33 \pm 0$ & $15.66 \pm 0$ & $14.66 \pm 1$ & $14.33 \pm 0$ & $14.66 \pm 1$ & $15.33 \pm 0$ & $15.66 \pm 0$ & $15.66 \pm 0$ & $15.33 \pm 0$ \\
\hline & .47 & .47 & .47 & .47 & .47 & .24 & .47 & .24 & .47 & .47 & .47 & .47 \\
\hline \multirow[t]{2}{*}{$8 a$} & $15.33 \pm 0$ & $12.66 \pm 0$ & $13.33 \pm 0$ & $13.33 \pm 0$ & $13.33 \pm 0$ & $13.33 \pm 0$ & $10.66 \pm 0$ & $12.33 \pm 0$ & $13.33 \pm 0$ & $13.33 \pm 0$ & $12.66 \pm 0$ & $12.66 \pm 0$ \\
\hline & .47 & .47 & .94 & .94 & .94 & .94 & .47 & .47 & .94 & .94 & .47 & .47 \\
\hline \multirow[t]{2}{*}{$8 b$} & $14.33 \pm 0$ & $13.33 \pm 0$ & $12.33 \pm 0$ & $12.66 \pm 0$ & $12.33 \pm 0$ & $14.33 \pm 0$ & $14.33 \pm 0$ & $12.33 \pm 0$ & $12 \pm 0.81$ & $11.66 \pm 0$ & $12.66 \pm 0$ & $14.33 \pm 0$ \\
\hline & .47 & .94 & .47 & .47 & .47 & .47 & .47 & .47 & & .47 & .47 & .47 \\
\hline \multirow[t]{2}{*}{$8 c$} & $10.66 \pm 0$ & $9.33 \pm 0$ & $10.66 \pm 0$ & $10.66 \pm 0$ & $11.33 \pm 1$ & $10.33 \pm 0$ & $9.33 \pm 0$ & $10.66 \pm 0$ & $11.66 \pm 0$ & $10.66 \pm 0$ & $10.66 \pm 0$ & $12.33 \pm 0$ \\
\hline & .47 & 47 & .47 & .47 & .24 & .47 & 47 & .47 & .47 & .47 & .47 & .47 \\
\hline \multirow[t]{2}{*}{$8 d$} & $15.33 \pm 0$ & $15.66 \pm 0$ & $15.33 \pm 0$ & $16.66 \pm 1$ & $16.66 \pm 1$ & $16.66 \pm 1$ & $15 \pm 0.81$ & $15.33 \pm 0$ & $14.66 \pm 1$ & $14.66 \pm 0$ & $14.66 \pm 0$ & $14.33 \pm 0$ \\
\hline & .47 & .47 & .47 & .24 & .24 & .24 & & .47 & .24 & .47 & .47 & .47 \\
\hline Streptom & $15.66 \pm 0$ & $16.33 \pm 0$ & $15.66 \pm 0$ & $16.66 \pm 0$ & $17 \pm 0.81$ & $15 \pm 0.81$ & $15.33 \pm 0$ & $15.66 \pm 0$ & $14.33 \pm 0$ & $15.33 \pm 0$ & $15.66 \pm 0$ & $14.66 \pm 0$ \\
\hline ycin & .47 & .47 & .47 & .94 & & & & .47 & .47 & .47 & .47 & .47 \\
\hline
\end{tabular}

Note: Values are expressed as mean $\pm \operatorname{SD}(n=3)$

Table 3: Antifungal activity, size of inhibition zone $(\mathrm{mm})$ formed at different concentrations $(1000,500,250$ and $125 \mu \mathrm{g} / \mathrm{ml})$ of synthesized compounds $3,4,5$ and 6-8 (a-d)

\begin{tabular}{|c|c|c|c|c|c|c|c|c|c|c|c|c|}
\hline \multirow{3}{*}{$\begin{array}{l}\text { Compou } \\
\text { nd }\end{array}$} & \multicolumn{12}{|c|}{ Zone of inhibition in $\mathrm{mm}$} \\
\hline & \multicolumn{4}{|c|}{ Aspergillus nizer } & \multicolumn{4}{|c|}{ Aspergillus flavus } & \multicolumn{4}{|c|}{ Aspergillus oryzae } \\
\hline & 1000 & 500 & 250 & 125 & 1000 & 500 & 250 & 125 & 1000 & 500 & 250 & 125 \\
\hline 3 & $\begin{array}{l}12.33 \pm 0 \\
.47\end{array}$ & $\begin{array}{l}10.33 \pm 1 \\
.24\end{array}$ & $\begin{array}{l}7.66 \pm 0 . \\
94\end{array}$ & $\begin{array}{l}6.66 \pm 0 \\
94\end{array}$ & $\begin{array}{l}9.33 \pm 0 . \\
47\end{array}$ & $\begin{array}{l}9.66 \pm 0 . \\
47\end{array}$ & $\begin{array}{l}9.33 \pm 0 \\
47\end{array}$ & $\begin{array}{l}7.66 \pm 0 . \\
94\end{array}$ & $\begin{array}{l}9.33 \pm 0 . \\
47\end{array}$ & $\begin{array}{l}9.33 \pm 0 \\
47\end{array}$ & $8 \pm 0.81$ & $\begin{array}{l}7.66 \pm 0 . \\
94\end{array}$ \\
\hline 4 & $\begin{array}{l}10.66 \pm 0 \\
.47\end{array}$ & $\begin{array}{l}9.33 \pm 0 . \\
47\end{array}$ & $\begin{array}{l}7.66 \pm 0 . \\
94\end{array}$ & $\begin{array}{l}7.66 \pm 0 . \\
94\end{array}$ & $\begin{array}{l}9.33 \pm 0 . \\
47\end{array}$ & $\begin{array}{l}9.33 \pm 0 . \\
47\end{array}$ & $7 \pm 0.81$ & $\begin{array}{l}6.66 \pm 0 . \\
94\end{array}$ & $8 \pm 0.81$ & $\begin{array}{l}7.66 \pm 0 . \\
94\end{array}$ & $\begin{array}{l}9.33 \pm 0 . \\
47\end{array}$ & $\begin{array}{l}6.33 \pm 0 . \\
94\end{array}$ \\
\hline 5 & $\begin{array}{l}9.33 \pm 0 \\
47\end{array}$ & $\begin{array}{l}9.33 \pm 0 \\
47\end{array}$ & $\begin{array}{l}7.66 \pm 0 . \\
94\end{array}$ & $\begin{array}{l}6.66 \pm 0 . \\
94\end{array}$ & $\begin{array}{l}7.66 \pm 0 . \\
94\end{array}$ & $\begin{array}{l}7.66 \pm 0 . \\
94\end{array}$ & $\begin{array}{l}7.66 \pm 0 . \\
94\end{array}$ & $\begin{array}{l}6.33 \pm 0 . \\
94\end{array}$ & $\begin{array}{l}9.33 \pm 0 . \\
47\end{array}$ & $\begin{array}{l}7.66 \pm 0 . \\
94\end{array}$ & $\begin{array}{l}6.66 \pm 0 . \\
94\end{array}$ & $\begin{array}{l}6.66 \pm 0 . \\
94\end{array}$ \\
\hline $6 a$ & $\begin{array}{l}13.33 \pm 0 \\
.94\end{array}$ & $\begin{array}{l}10.33 \pm 1 \\
.24\end{array}$ & $\begin{array}{l}9.33 \pm 0 . \\
47\end{array}$ & $\begin{array}{l}9.33 \pm 0 . \\
47\end{array}$ & $\begin{array}{l}9.66 \pm 0 . \\
47\end{array}$ & $\begin{array}{l}12.66 \pm 0 \\
.47\end{array}$ & $\begin{array}{l}9.66 \pm 0 . \\
47\end{array}$ & $\begin{array}{l}12.33 \pm 0 \\
.47\end{array}$ & $\begin{array}{l}10.33 \pm 1 \\
.24\end{array}$ & $\begin{array}{l}10.66 \pm 0 \\
.47\end{array}$ & $\begin{array}{l}9.33 \pm 0 . \\
47\end{array}$ & $\begin{array}{l}12.33 \pm 0 \\
.47\end{array}$ \\
\hline $6 b$ & $\begin{array}{l}14.33 \pm 0 \\
.47\end{array}$ & $\begin{array}{l}14.33 \pm 0 \\
.47\end{array}$ & $\begin{array}{l}13.33 \pm 0 \\
.94\end{array}$ & $\begin{array}{l}12.66 \pm 0 \\
.47\end{array}$ & $\begin{array}{l}14.33 \pm 0 \\
.91\end{array}$ & $\begin{array}{l}13.33 \pm 0 \\
.94\end{array}$ & $\begin{array}{l}14.33 \pm 0 \\
.91\end{array}$ & $\begin{array}{l}14.33 \pm 0 \\
.47\end{array}$ & $\begin{array}{l}14.33 \pm 0 \\
.47\end{array}$ & $\begin{array}{l}14.33 \pm 0 \\
.47\end{array}$ & $\begin{array}{l}14.33 \pm 0 \\
.47\end{array}$ & $\begin{array}{l}14.33 \pm 0 \\
.47\end{array}$ \\
\hline $6 c$ & $\begin{array}{l}13.33 \pm 0 \\
.94\end{array}$ & $\begin{array}{l}13.33 \pm 0 \\
.94\end{array}$ & $\begin{array}{l}12.33 \pm 0 \\
.47\end{array}$ & $\begin{array}{l}12.33 \pm 0 \\
.47\end{array}$ & $\begin{array}{l}12.33 \pm 0 \\
.47\end{array}$ & $\begin{array}{l}10.33 \pm 1 \\
.24\end{array}$ & $\begin{array}{l}12.66 \pm 0 \\
.47\end{array}$ & $\begin{array}{l}12.33 \pm 0 \\
.47\end{array}$ & $\begin{array}{l}13.33 \pm 0 \\
.94\end{array}$ & $\begin{array}{l}12.66 \pm 0 \\
.47\end{array}$ & $\begin{array}{l}10.66 \pm 0 \\
.47\end{array}$ & $\begin{array}{l}10.33 \pm 0 \\
.47\end{array}$ \\
\hline $6 \mathrm{~d}$ & $\begin{array}{l}10.66 \pm 0 \\
.47\end{array}$ & $\begin{array}{l}12.66 \pm 0 \\
.47\end{array}$ & $\begin{array}{l}10.66 \pm 0 \\
.47\end{array}$ & $\begin{array}{l}13.66 \pm 0 \\
.94\end{array}$ & $\begin{array}{l}10.66 \pm 0 \\
.47\end{array}$ & $\begin{array}{l}12.66 \pm 0 \\
.47\end{array}$ & $\begin{array}{l}12.66 \pm 0 \\
.91\end{array}$ & $\begin{array}{l}13.33 \pm 0 \\
.94\end{array}$ & $\begin{array}{l}13.33 \pm 0 \\
.94\end{array}$ & $\begin{array}{l}12.66 \pm 0 \\
.47\end{array}$ & $\begin{array}{l}12.33 \pm 0 \\
.47\end{array}$ & $\begin{array}{l}13.33 \pm 0 \\
.47\end{array}$ \\
\hline $7 a$ & $\begin{array}{l}14.33 \pm 0 \\
.47\end{array}$ & $\begin{array}{l}12.33 \pm 0 \\
.47\end{array}$ & $\begin{array}{l}13.33 \pm 0 \\
.94\end{array}$ & $\begin{array}{l}13.33 \pm 0 \\
.94\end{array}$ & $\begin{array}{l}13.33 \pm 0 \\
.94\end{array}$ & $\begin{array}{l}12.33 \pm 0 \\
.47\end{array}$ & $\begin{array}{l}10.66 \pm 0 \\
.47\end{array}$ & $\begin{array}{l}12.33 \pm 0 \\
.47\end{array}$ & $\begin{array}{l}12.66 \pm 0 \\
.47\end{array}$ & $\begin{array}{l}10.33 \pm 1 \\
.24\end{array}$ & $\begin{array}{l}10.33 \pm 0 \\
.47\end{array}$ & $\begin{array}{l}13.33 \pm 0 \\
.94\end{array}$ \\
\hline $7 b$ & $\begin{array}{l}13.33 \pm 0 \\
.94\end{array}$ & $\begin{array}{l}12.66 \pm 0 \\
.47\end{array}$ & $\begin{array}{l}10.66 \pm 0 \\
.47\end{array}$ & $\begin{array}{l}12.66 \pm 0 \\
.91\end{array}$ & $\begin{array}{l}12.66 \pm 0 \\
.47\end{array}$ & $\begin{array}{l}12.33 \pm 0 \\
.47\end{array}$ & $\begin{array}{l}10.66 \pm 0 \\
.91\end{array}$ & $\begin{array}{l}14.33 \pm 0 \\
.47\end{array}$ & $\begin{array}{l}13.33 \pm 0 \\
.47\end{array}$ & $\begin{array}{l}10.66 \pm 0 \\
.47\end{array}$ & $\begin{array}{l}10.66 \pm 0 \\
.47\end{array}$ & $\begin{array}{l}12.33 \pm 0 \\
.47\end{array}$ \\
\hline $7 \mathrm{c}$ & $\begin{array}{l}12.33 \pm 0 \\
.47\end{array}$ & $\begin{array}{l}10.33 \pm 1 \\
.24\end{array}$ & $\begin{array}{l}10.66 \pm 0 \\
.47\end{array}$ & $\begin{array}{l}12.33 \pm 0 \\
.47\end{array}$ & $\begin{array}{l}12.33 \pm 0 \\
.47\end{array}$ & $\begin{array}{l}12.66 \pm 0 \\
.47\end{array}$ & $\begin{array}{l}10.33 \pm 0 \\
.47\end{array}$ & $\begin{array}{l}13.33 \pm 0 \\
.94\end{array}$ & $\begin{array}{l}13.33 \pm 0 \\
.94\end{array}$ & $\begin{array}{l}12.33 \pm 0 \\
.47\end{array}$ & $\begin{array}{l}9.33 \pm 0 . \\
47\end{array}$ & $\begin{array}{l}12.66 \pm 0 \\
.47\end{array}$ \\
\hline $7 d$ & $\begin{array}{l}15.66 \pm 0 \\
.47\end{array}$ & $\begin{array}{l}14.66 \pm 0 \\
.47\end{array}$ & $\begin{array}{l}13.33 \pm 0 \\
.94\end{array}$ & $\begin{array}{l}13.33 \pm 0 \\
.94\end{array}$ & $\begin{array}{l}14.66 \pm 0 \\
.47\end{array}$ & $\begin{array}{l}14.33 \pm 0 \\
.47\end{array}$ & $\begin{array}{l}14.33 \pm 0 \\
.91\end{array}$ & $\begin{array}{l}14.33 \pm 0 \\
.47\end{array}$ & $\begin{array}{l}15.66 \pm 0 \\
.47\end{array}$ & $\begin{array}{l}15.66 \pm 0 \\
.47\end{array}$ & $\begin{array}{l}14.33 \pm 0 \\
.47\end{array}$ & $\begin{array}{l}14.33 \pm 0 \\
.47\end{array}$ \\
\hline $8 a$ & $\begin{array}{l}14.66 \pm 0 \\
.47\end{array}$ & $\begin{array}{l}13.33 \pm 0 \\
.94\end{array}$ & $\begin{array}{l}12.33 \pm 0 \\
.47\end{array}$ & $\begin{array}{l}12.33 \pm 0 \\
.47\end{array}$ & $\begin{array}{l}13.33 \pm 0 \\
.94\end{array}$ & $\begin{array}{l}12.66 \pm 0 \\
.47\end{array}$ & $\begin{array}{l}13.33 \pm 0 \\
.94\end{array}$ & $\begin{array}{l}12.33 \pm 0 \\
.47\end{array}$ & $\begin{array}{l}14.33 \pm 0 \\
.47\end{array}$ & $\begin{array}{l}14.33 \pm 0 \\
.47\end{array}$ & $\begin{array}{l}12.33 \pm 0 \\
.47\end{array}$ & $\begin{array}{l}12.66 \pm 0 \\
.47\end{array}$ \\
\hline $8 b$ & $\begin{array}{l}13.33 \pm 0 \\
.94\end{array}$ & $\begin{array}{l}10.33 \pm 0 \\
.47\end{array}$ & $\begin{array}{l}10.33 \pm 1 \\
.24\end{array}$ & $\begin{array}{l}13.33 \pm 0 \\
.94\end{array}$ & $\begin{array}{l}10.66 \pm 0 \\
.47\end{array}$ & $\begin{array}{l}12.66 \pm 0 \\
.47\end{array}$ & $\begin{array}{l}13.33 \pm 0 \\
.47\end{array}$ & $\begin{array}{l}12.33 \pm 0 \\
.47\end{array}$ & $\begin{array}{l}13.33 \pm 0 \\
.94\end{array}$ & $\begin{array}{l}13.33 \pm 0 \\
.94\end{array}$ & $\begin{array}{l}9.66 \pm 0 . \\
47\end{array}$ & $\begin{array}{l}12.66 \pm 0 \\
.47\end{array}$ \\
\hline $8 c$ & $\begin{array}{l}12.33 \pm 0 \\
.47\end{array}$ & $\begin{array}{l}12.66 \pm 0 \\
.47\end{array}$ & $\begin{array}{l}12.66 \pm 0 \\
.47\end{array}$ & $\begin{array}{l}12.33 \pm 0 \\
.47\end{array}$ & $\begin{array}{l}12.66 \pm 0 \\
.47\end{array}$ & $\begin{array}{l}12.66 \pm 0 \\
.47\end{array}$ & $\begin{array}{l}13.33 \pm 0 \\
.94\end{array}$ & $\begin{array}{l}13.33 \pm 0 \\
.94\end{array}$ & $\begin{array}{l}13.33 \pm 0 \\
.94\end{array}$ & $\begin{array}{l}14.33 \pm 0 \\
.47\end{array}$ & $\begin{array}{l}14.33 \pm 0 \\
.47\end{array}$ & $\begin{array}{l}14.66 \pm 0 \\
.47\end{array}$ \\
\hline $8 d$ & $\begin{array}{l}14.66 \pm 0 \\
.47\end{array}$ & $\begin{array}{l}14.33 \pm 0 \\
.47\end{array}$ & $\begin{array}{l}14.33 \pm 0 \\
.47\end{array}$ & $\begin{array}{l}14.33 \pm 0 \\
.47\end{array}$ & $\begin{array}{l}15.66 \pm 0 \\
.47\end{array}$ & $\begin{array}{l}14.33 \pm 0 \\
.47\end{array}$ & $\begin{array}{l}14.66 \pm 0 \\
.47\end{array}$ & $\begin{array}{l}14.33 \pm 0 \\
.47\end{array}$ & $\begin{array}{l}15.66 \pm 0 \\
.47\end{array}$ & $\begin{array}{l}15.33 \pm 0 \\
.47\end{array}$ & $\begin{array}{l}15.33 \pm 0 \\
.47\end{array}$ & $\begin{array}{l}14.66 \pm 0 \\
.47\end{array}$ \\
\hline $\begin{array}{l}\text { Flucona } \\
\text { zole }\end{array}$ & $\begin{array}{l}15.66 \pm 0 \\
.47\end{array}$ & $\begin{array}{l}15.33 \pm 0 \\
.94\end{array}$ & $\begin{array}{l}14.66 \pm 0 \\
.47\end{array}$ & $\begin{array}{l}14.66 \pm 0 \\
.91\end{array}$ & $\begin{array}{l}16.33 \pm 0 \\
.47\end{array}$ & $15 \pm 0.81$ & $\begin{array}{l}15.33 \pm 0 \\
.47\end{array}$ & $\begin{array}{l}14.33 \pm 0 \\
.47\end{array}$ & $\begin{array}{l}16.66 \pm 0 \\
.94\end{array}$ & $\begin{array}{l}15.66 \pm 0 \\
.47\end{array}$ & $\begin{array}{l}15.66 \pm 0 \\
.47\end{array}$ & $\begin{array}{l}15.66 \pm 0 \\
.47\end{array}$ \\
\hline
\end{tabular}

Note: Values are expressed as mean $\pm \mathrm{SD}(\mathrm{n}=3)$ 


\section{Antimicrobial activity}

The analysis of antibacterial screening (table 2) revealed that all compounds tested, have moderate to high antibacterial activity as compared to the standard drug streptomycin. These results are better in comparison with the earlier reported ones, this might be because of the presence of benzimidazole ring and amide group in addition to the indole ring [7]. The molecules $6 \mathrm{~d}$ (the molecule having bromo substitution at $5^{\text {th }}$ position of indole ring), $8 \mathrm{~b}$ (chloro substitution at $5^{\text {th }}$ position of indole ring) and 8d (Bromo substitution at $5^{\text {th }}$ position of indole ring) showed excellent antibacterial activity against the tested microorganism S. aureus (ATCC-29513). The compounds 7d (bromo substitution at $5^{\text {th }}$ position of indole ring and methoxy substitution at $5^{\text {th }}$ position of benzimidazole ring) and $8 \mathrm{~d}$ (bromo substitution at $5^{\text {th }}$ position of indole ring) have exhibited good activity against E. coli (MTCC-723). Whereas, the compounds 6d (bromo substitution at $5^{\text {th }}$ position of indole ring), $7 \mathrm{~d}$ (bromo substitution at $5^{\text {th }}$ position of indole ring and methoxy substitution at $5^{\text {th }}$ position of benzimidazole ring), 8a (the molecule possesses indole and benzothiazole rings) and 8d (bromo substitution at $5^{\text {th }}$ position of indole ring) displayed good activity against $P$. aeruginosa (MTCC-1688).

On the other hand, the antifungal activity results (table 3) discovered that, the compounds $6 \mathrm{~b}$ (the molecule having chloro substitution at $5^{\text {th }}$ position of indole ring), $7 \mathrm{~d}$ (bromo substitution at $5^{\text {th }}$ position of indole ring and methoxy substitution at $5^{\text {th }}$ position of benzimidazole ring) and $8 \mathrm{~d}$ (bromo substitution at $5^{\text {th }}$ position of indole ring) have revealed profound activity against $A$. niger (MTCC281), A. flavus (MTCC-1782) and A. oryzae (MTCC-3567T).

The rest of the compounds were found to exhibit moderate activity against the bacterial or fungal strains.

\section{Antioxidant activities}

1, 1-Diphenyl-2-picryl hydrazyl (DPPH) radical scavenging activity (RSA)

In vitro method of scavenging of the stable DPPH radical is extensively used to evaluate the antioxidant activity in less time than other methods. DPPH is a stable free radical that can accept hydrogen radical or an electron and must thus be converted to a stable diamagnetic molecule. DPPH has an odd electron and so has a strong absorption band at $517 \mathrm{~nm}$. When this electron becomes paired off, the absorption decreases stoichiometrically with respect to the number of electrons or hydrogen atoms taken up. The DPPH antioxidant assay measures the hydrogen donating capacity of the molecules under study. When the free-radical DPPH is reduced by the sample, its colour changes from violet to yellow. The results (fig. 1 to 4 ) suggested that compounds $6 \mathrm{~b}, 8 \mathrm{a}$ and $8 \mathrm{~b}$ showed promising RSA at all concentrations. Compounds $3,6 \mathrm{~b}, 8 \mathrm{a}, 8 \mathrm{~b}$ and $8 \mathrm{c}$ were found to enhance the RSA 52.07, 62.13, 57.39, 56.80 and $56.80 \%$ respectively at conc. $25 \mu \mathrm{g} / \mathrm{ml}$. Compounds $6 \mathrm{~b}, 8 \mathrm{a}, 8 \mathrm{~b}$ and $8 \mathrm{c}$ showed good activity i. e; $65.38,61.24,61.83$ and $62.42 \%$ respectively at conc. $50 \mu \mathrm{g} / \mathrm{ml}$ and $68.34,70.71,67.15$ and $64.79 \%$ respectively at conc. $75 \mu \mathrm{g} / \mathrm{ml}$. Compound $5,6 \mathrm{~b}, 7 \mathrm{a}, 7 \mathrm{~b}, 8 \mathrm{a}$ and $8 \mathrm{~b}$ showed promising activity i. e; 71.00, 72.18, 70.71, 73.66, 73.96 and $72.78 \%$ respectively at conc. $100 \mu \mathrm{g} / \mathrm{ml}$. Among all the synthesized compounds, compound $6 \mathrm{~b}$ exhibited the highest activity at all the concentrations this may be due to the presence of chlorine substituent at $5^{\text {th }}$ position of the indole ring. The rest of the compounds were found to enhance the RSA to a lesser extent. However, none of the compounds exhibited better RSA than the standard.

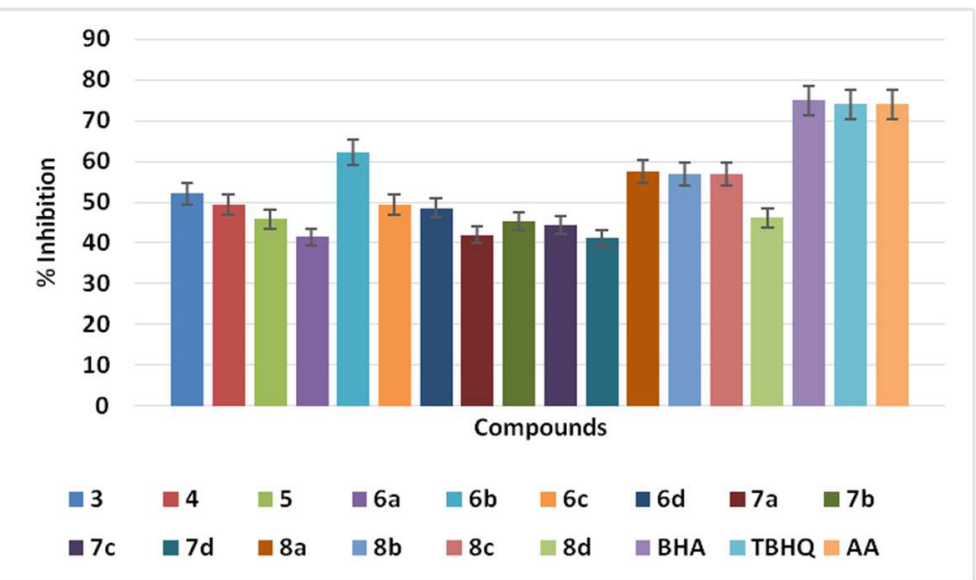

Fig. 1: DPPH radical scavenging activity of synthesized compounds at conc. $25 \mu \mathrm{g} / \mathrm{ml}$, The graph represents the $m e a n \pm S E M,(n=3), P<0.01$ significant compared to the standard group

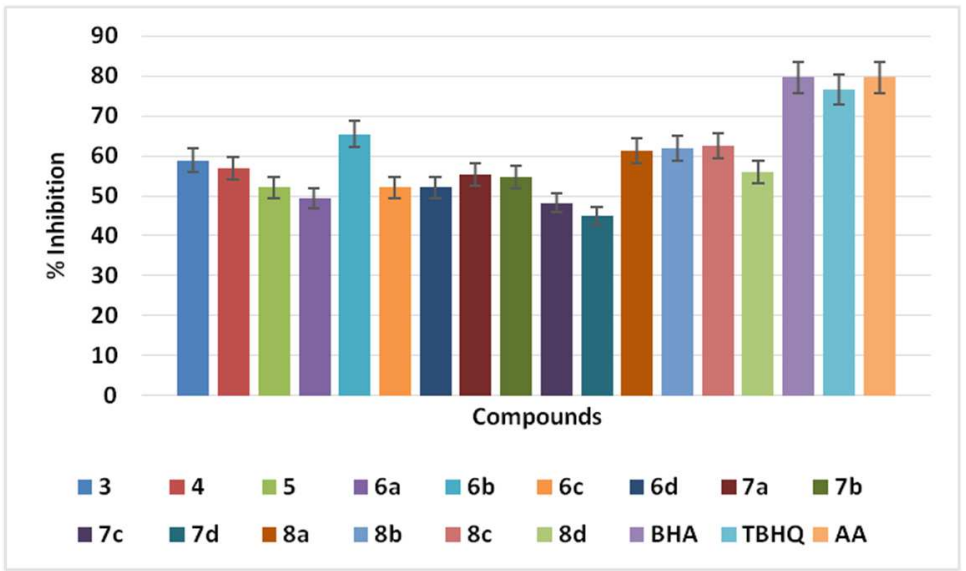

Fig. 2: DPPH radical scavenging activity of synthesized compounds at conc. $50 \mu \mathrm{g} / \mathrm{ml}$, The graph represents the $m e a n \pm S E M,(n=3)$, $P<0.01$ significant compared to the standard group 


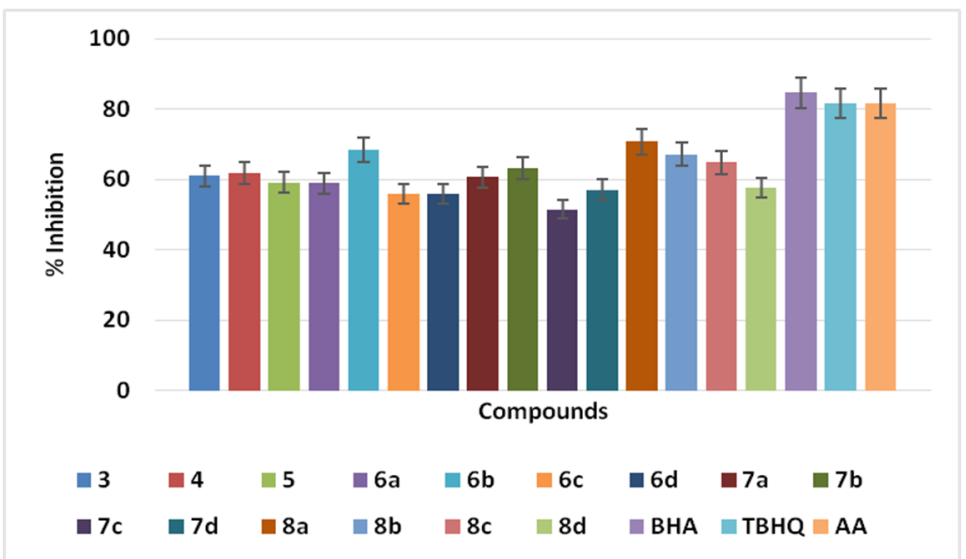

Fig. 3: DPPH radical scavenging activity of synthesized compounds at conc. $75 \mu \mathrm{g} / \mathrm{ml}$, The graph represents the mean $\pm \mathrm{SEM},(\mathrm{n}=3)$, $\mathrm{P}<0.01$ significant compared to the standard group

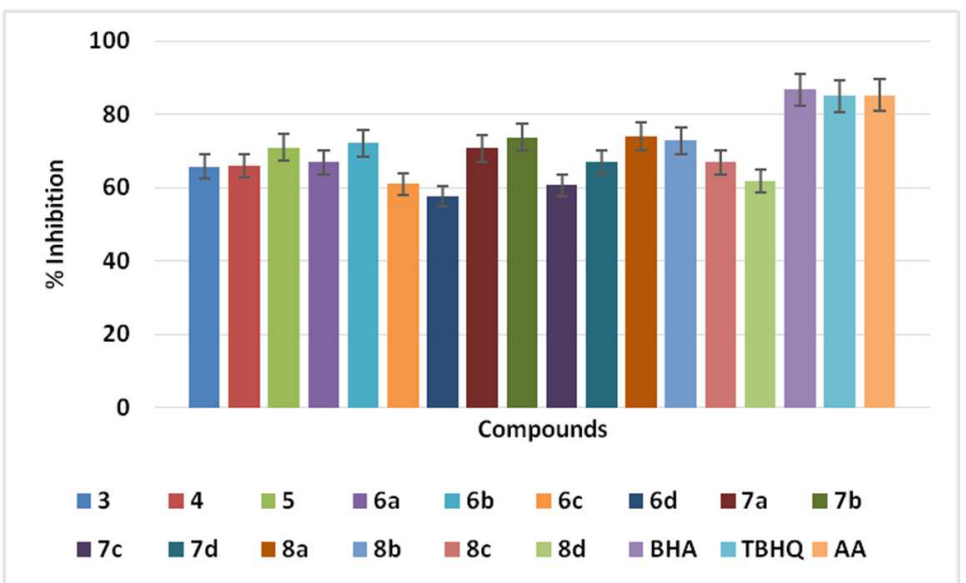

Fig. 4: DPPH radical scavenging activity of synthesized compounds at conc. $100 \mu \mathrm{g} / \mathrm{ml}$. The graph represents the mean $\pm \mathrm{SEM},(\mathrm{n}=3)$, $P<0.01$-significant compared to the standard group

\section{Ferric ions $\left(\mathrm{Fe}^{3+}\right)$ reducing antioxidant power (FRAP)}

The FRAP results (fig. 5 to 8) suggested that, the compounds 7a-d and 8b-d showed good absorbance $0.893,0.911,0.894,0.894,0.874,0.851$, and $0.831 \mathrm{~nm}$ at concentration $100 \mu \mathrm{g} / \mathrm{ml}$, indicating that these compounds have good ferric ions $\left(\mathrm{Fe}^{3+}\right)$ reducing antioxidant power at concentrations of $100 \mu \mathrm{g} / \mathrm{ml}$. In other words, these compounds showed the ability of electron donor to scavenge free radicals. Among the synthesized compounds 7a-d have exhibited highest ferric ions $\left(\mathrm{Fe}^{3+}\right)$ reducing antioxidant power at concentration $100 \mu \mathrm{g} / \mathrm{ml}$. This may be due to the presence of methoxy substituent at 5-position of benzimidazole ring. The rest of the compounds showed lower absorbance as related to the standards. The higher the absorbance of the compounds indicated greater reducing power.

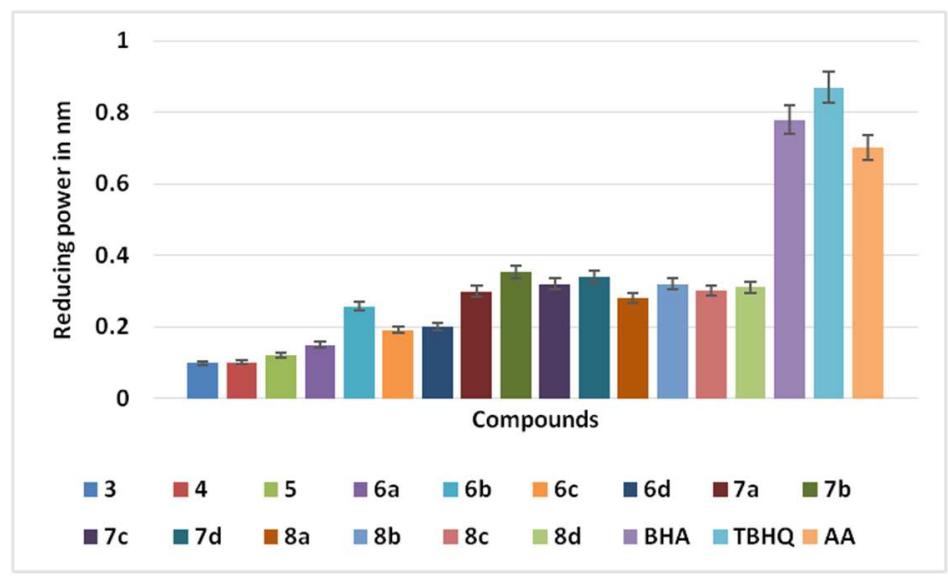

Fig. 5: Reducing power activity of synthesized compounds at conc. $25 \mu \mathrm{g} / \mathrm{ml}$, The graph represents the mean $\pm S E M,(n=3), P<0.01$ significant compared to the standard group 


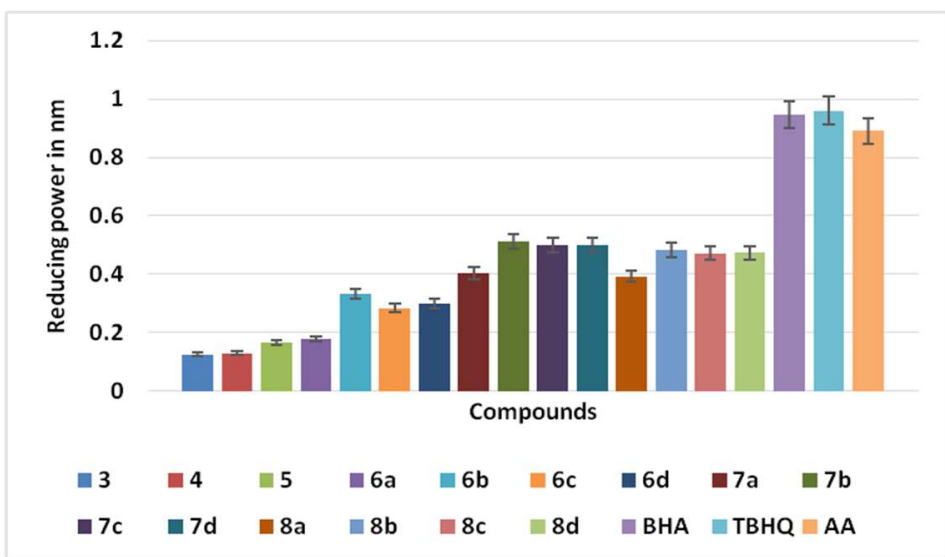

Fig. 6: Reducing power activity of synthesized compounds at conc. $50 \mu \mathrm{g} / \mathrm{ml}$, The graph represents the mean \pm SEM, $(n=3)$, $P<0.01$ significant compared to the standard group

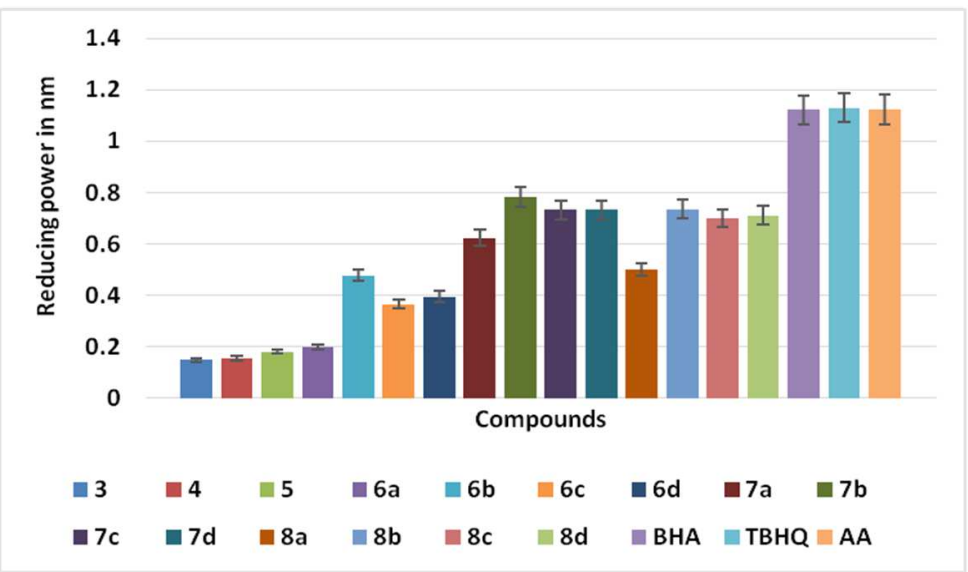

Fig. 7: Reducing power activity of synthesized compounds at conc. $75 \mu \mathrm{g} / \mathrm{ml}$, The graph represents the mean \pm SEM, $(\mathrm{n}=3)$, $P<0.01$ significant compared to the standard group

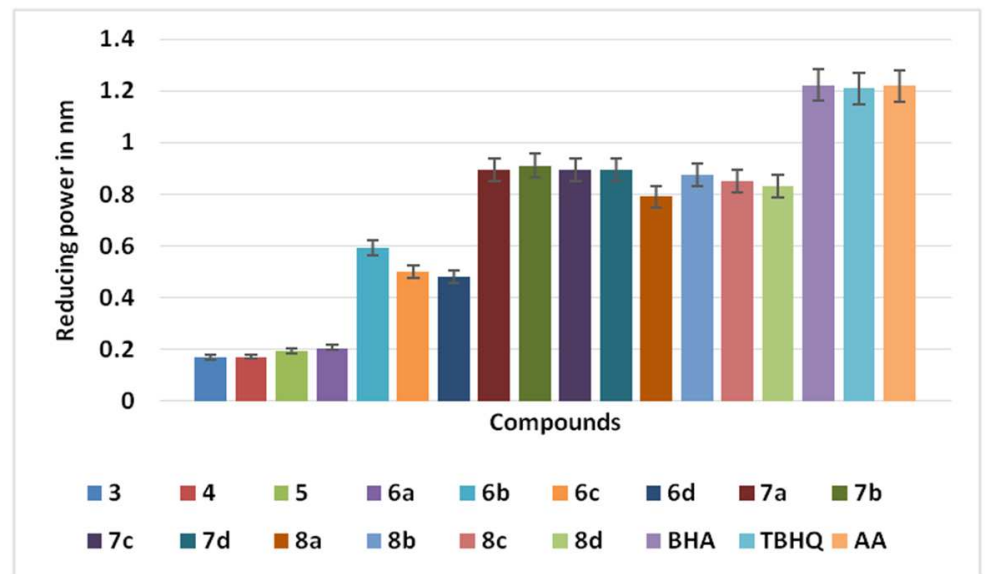

Fig. 8: Reducing power activity of synthesized compounds at conc. $100 \mu \mathrm{g} / \mathrm{ml}$, The graph represents the mean \pm SEM, $(\mathrm{n}=3)$, $P<0.01$ significant compared to the standard group

\section{Ferrous $\left(\mathrm{Fe}^{2+}\right)$ metal ion chelating activity}

Ferrous $\left(\mathrm{Fe}^{2+}\right)$ metal ion chelating activity results (fig. 9 to 12) revealed that synthesized compounds obstructed the formation of ferrous and ferrozine complex. Compounds $6 \mathrm{~b}, 7 \mathrm{~b}, 7 \mathrm{~d}, 8 \mathrm{~b}$ and $8 \mathrm{~d}$ exhibited $(69.75,75.00,74.38,78.08$ and $75.61 \%)$ good metal chelating activity at concentration of $100 \mu \mathrm{g} / \mathrm{ml}$. Compound $7 \mathrm{c}$ and $8 \mathrm{c}$ also showed the highest (69.44 and $73.76 \%$ ) metal chelating activity at concentration $100 \mu \mathrm{g} / \mathrm{ml}$. This may be due to the presence of a chlorine/bromine atom at 5-position of the indole ring and methoxy substituent 5-position of benzimidazole ring. The highest metal chelating activity of these compounds indicates that these compounds are able to capture ferrous ion before ferrozine. This might be the reason for the higher metal chelating activity. The rest of the compounds showed reasonable to less activity when compared with the standard drugs. 


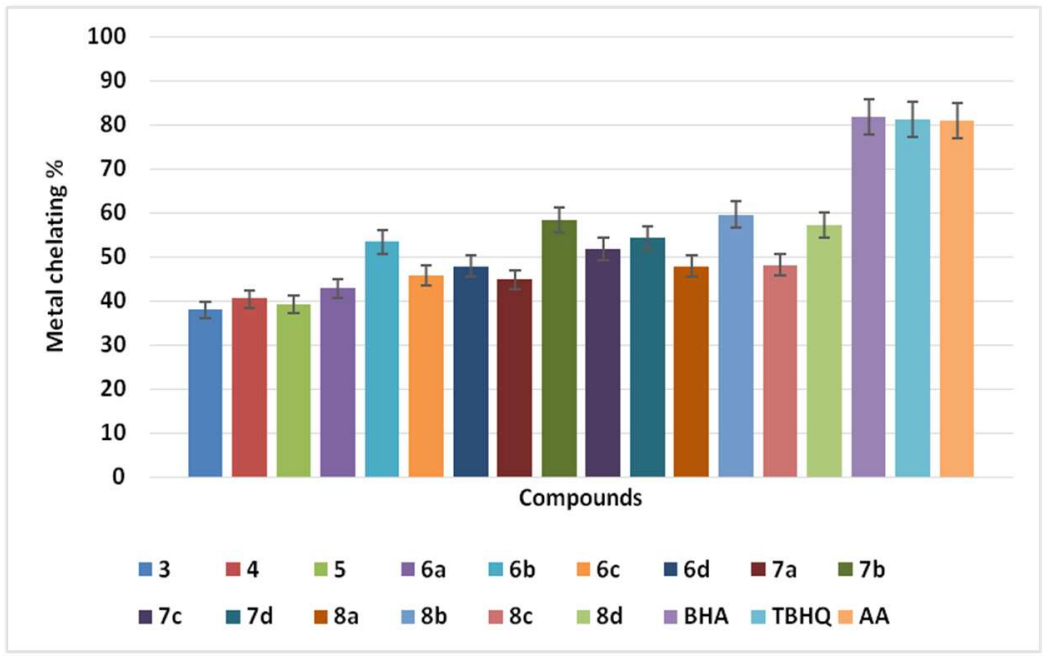

Fig. 9: Metal chelating activity of synthesized compounds at conc. $25 \mu \mathrm{g} / \mathrm{ml}$, The graph represents the mean $\pm S E M,(n=3), P<0.01$ significant compared to the standard group

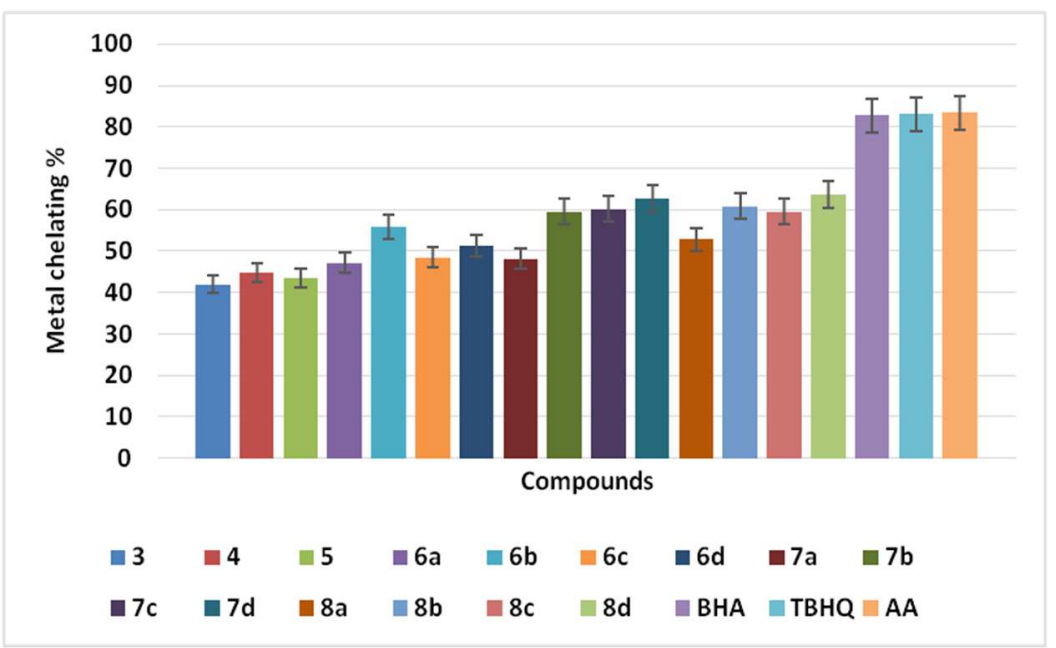

Fig. 10: Metal chelating activity of synthesized compounds at conc. $50 \mu \mathrm{g} / \mathrm{ml}$, The graph represents the mean $\pm S E M,(n=3), P<0.01$ significant compared to the standard group

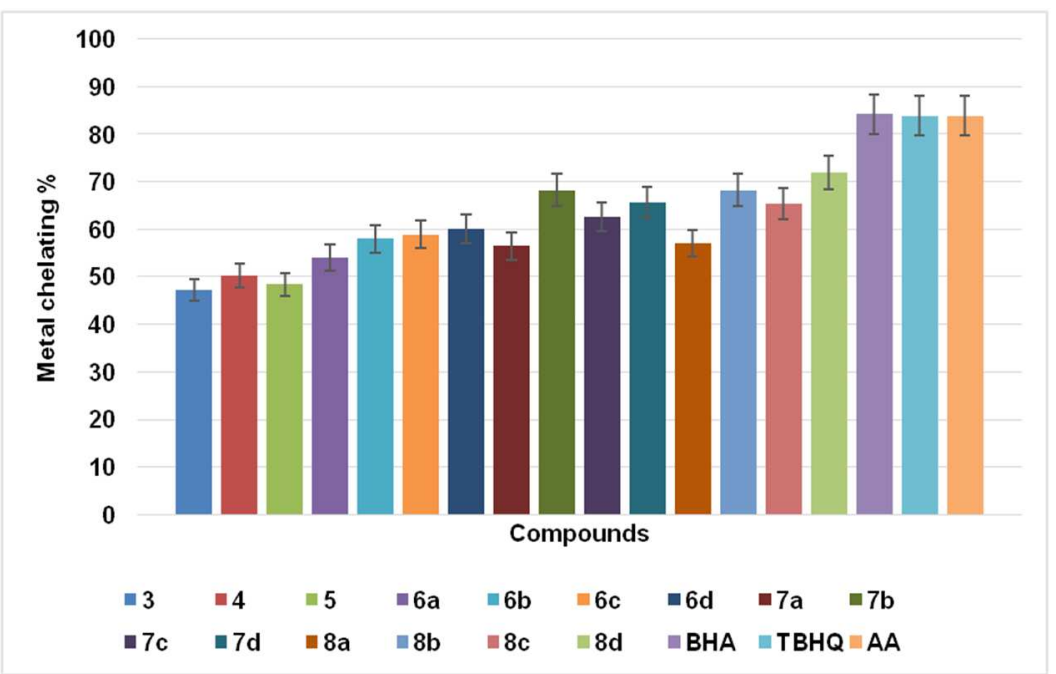

Fig. 11: Metal chelating activity of synthesized compounds at conc. $75 \mu \mathrm{g} / \mathrm{ml}$, The graph represents the mean $\pm S E M,(n=3), P<0.01$ significant compared to the standard group 


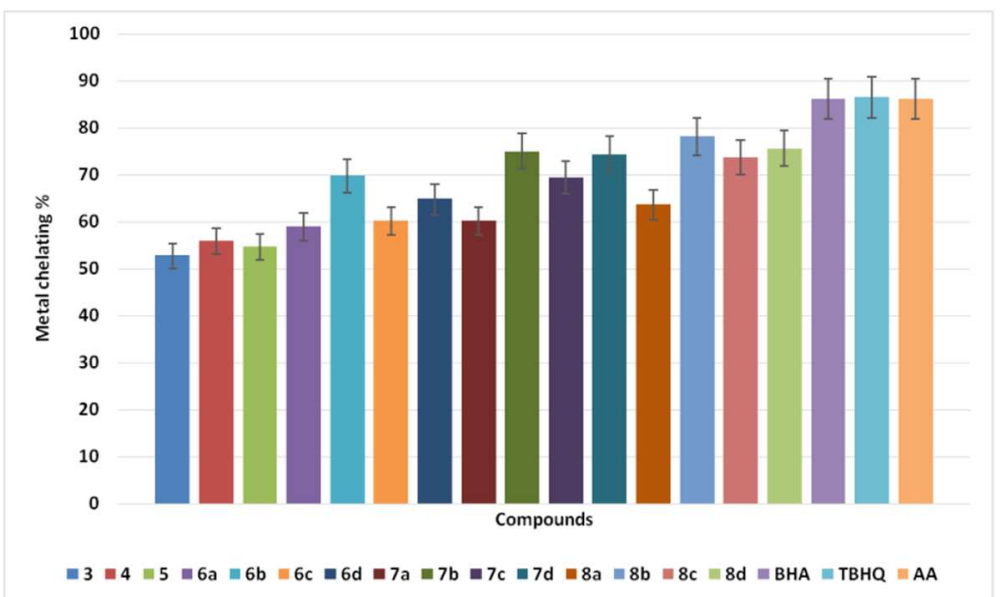

Fig. 12: Metal chelating activity of synthesized compounds at conc. $100 \mu \mathrm{g} / \mathrm{ml}$, The graph represents the mean $\pm S E M,(n=3), P<0.01$ significant compared to the standard group

\section{CONCLUSION}

The title compound of indole derivatives attached with benzimidazole/benzothiazole were synthesised and characterized by spectral and analytical data. All the compounds were subjected for antimicrobial, antifungal and antioxidant screening. We found that compounds $6 \mathrm{~b}, 6 \mathrm{~d}, 7 \mathrm{a}, 7 \mathrm{~d}, 8 \mathrm{a}-\mathrm{b}$ and $8 \mathrm{~d}$ are active towards antibacterial and antifungal strains. Compounds $6 \mathrm{~b}, 7 \mathrm{a}-\mathrm{d}$ and $8 \mathrm{a}-\mathrm{d}$, showed potent antioxidant activity compared to the standard. These studies may promote further expansion of the indole derivatives bearing benzimidazole/benzothiazole moieties, which may lead to compounds with potent antioxidant and antimicrobial activities. Based on these results, selected novel compounds are being screened in vivo which will be reported in due course.

\section{AUTHORS CONTRIBUTION}

J. S. Biradar the corresponding author made substantial contributions to conception and design, acquisition of data, analysis and interpretation of data.

Author carried out the experimental part, conducting the pharmacological evaluation, drafting the article and revising it critically for important intellectual content.

\section{ACKNOWLEDGEMENT}

The authors sincerely acknowledge UGC-BSR, No. F.25-1/2013-14 (BSR)/No. F.7-226/2009 (BSR) dated 19th Nov 2014, New Delhi (India) for financial support. The authors are thankful to the Chairman, Department of Chemistry, Gulbarga University, Kalaburagi for providing laboratory facilities; to the Chairman, Department of Biochemistry, Gulbarga University, Kalaburagi for providing facilities to carry out antimicrobial activity. Also thankful to the Director, CIL, Panjab University, Chandigarh and to the Director, IIT, Madras, Chennai for providing spectral data. Authors are also thankful for BioGenics Research and Training Centre in Biotechnology, Hubli for biological studies.

\section{CONFLICT OF INTERESTS}

Declared none

\section{REFERENCES}

1. Stansfield I, Pompei M, Conte I, Ercolani C, Migliaccio G, Jairaj $\mathrm{M}$, et al. Development of carboxylic acid replacements in indole-N-acetamide inhibitors of hepatitis C virus NS5B polymerase. Bioorg Med Chem Lett 2007;17:5143-9.

2. Li YY, Wu HS, Tang L, Feng CR, Yu JH, Li Y, et al. The potential insulin sensitizing and glucose lowering effects of a novel indole derivative in vitro and in vivo. Pharmcol Res 2007;56:335-43.

3. RJ Sundberg. The Chemistry of Indoles. New York: Academic Press; 1996.
4. Mezencev R, Kutschy P, Salayova A, Updegrove T, McDonald JF. The design, synthesis and anticancer activity of new nitrogen mustard derivatives of natural indole phytoalexin 1methoxyspirobrassinol. Neoplasma 2009;56:321-30.

5. Mardia TEl Sayed, Nehal A Hamdy, Dalia A Osman, Khadiga M Ahmed. Indoles as anti-cancer agents. Adv Mod Oncol Res 2015;1:20-35.

6. Biradar JS, Sasidhar BS, Parveen R. Synthesis, antioxidant and DNA cleavage activities of novel indole derivatives. Eur J Med Chem 2010;45:4074-8.

7. Biradar JS, Somappa SB. Synthesis of novel Indolyl benzo[b][1,4]diazepins as a potent antimicrobial and antioxidant agents. Arab J Chem 2016;9(S2):S1063-S1068.

8. Guerra AS, Malta DJ, Laranjeira LP, Maia MB, Colaço NC, de Lima Mdo C, et al. Anti-inflammatory and antinociceptive activities of indole-imidazolidine derivatives. Int Immunopharmacol 2011;11:1816-22.

9. Vibha C Patil, Kishore P Bhusari, Pramod B Khedekar. Synthesis and anti-inflammatory activity of some 3-substituted thiazolyl and oxazolyl indole derivatives. World J Pharm Pharma Sci 2014;3:1292-306.

10. Ming-Zhi Zhang, Qiong Chen, Guang-Fu Yang. A review on recent developments of indole-containing antiviral agents. Eur J Med Chem 2015;89:421-41.

11. Saravanan B, Akhilesh Upgade, Anusha Bhaskar, Manivannan V. Synthesis and molecular docking studies of diethyl 2-\{[3-(2,4,6trimethyl benzyl)-1-phenylsulfonyl-1h-indol-2-yl]methylidene\} propanedioate against hypertensive protein as a potential target. Asian J Pharm Clin Res 2013;6:172-4.

12. P Lavanya, M Suresh, Y Kotaiah, N Harikrishna, C Venkata Rao. Synthesis, antibacterial, antifungal and antioxidant activity studies on 6-bromo-2-substituted phenyl-1H-imidazo [4, 5-b] pyridine. Asian J Pharm Clin Res 2011;4:69-73.

13. Gaozhi Chen, Zhiguo Liu, Yali Zhang, Xiaoou Shan, Lili Jiang, Yunjie Zhao, et al. Synthesis and anti-inflammatory evaluation of novel benzimidazole and imidazopyridine derivatives. ACS Med Chem Lett 2013;4:69-74.

14. Y Radha, A manjula, B Madhava Reddy, B Vittal Rao. Synthesis and biological activity of novel benzimidazoles. Indian J Chem 2011. p. 1762-73

15. Mi Kyoung Kim, Heerim Shin, Kwang-su Park, Hyungmi Kim, Jiseon Park, Kangjeon Kim. Benzimidazole derivatives as potent JAK1-selective inhibitors. J Med Chem 2015;58:7596-602.

16. Vivek K Vyas, Manjunath Ghate. QSAR modelling of substituted benzimidazole derivative as angiotensin $\mathrm{II}_{-} \mathrm{AT}_{1}$ receptor antagonist: WHIM descriptors. Int J Drug Des Discovery 2011;1:375-82

17. Tonelli M, Simone M, Tasso B, Novelli F, Boido V, Sparatore F, et al. Antiviral activity of benzimidazole derivatives. II. Antiviral activity of 2-phenyl benzimidazole derivatives. Bioorg Med Chem 2010;18:2937-53. 
18. Shingalapur RV, Hosamani KM, Keri RS, Hugar MH. Derivatives of benzimidazole pharmacophore: synthesis, anticonvulsant, antidiabetic and DNA cleavage studies. Eur J Med Chem 2010;45:1753-9.

19. Ramanatham Vinodkumar, Sanjay Dashrath Vaidya, Bobba Venkata Siva Kumar, Umesh Nanasaheb Bhise, Shekhar Bhaskar Bhirud, Uday Chandrakant Mashelkar. Synthesis, anti-bacterial, anti-asthmatic and anti-diabetic activities of novel N-substituted-2(4-phenylethynyl-phenyl)-1H-benzimidazoles and N-substituted 2[4-(4,4-dimethyl-thiochroman-6-yl-ethynyl)-phenyl)-1H-benzimidazoles. Eur J Med Chem 2008;43:986-95.

20. Suresh Maddila, Sridevi Gorle, Nuthangi Seshadri, Palakondu Lavanya, Sreekanth, B Jonnalagadda. Synthesis, antibacterial and antifungal activity of novel benzothiazole pyrimidine derivatives. Arab J Chem 2016;9:681-7.

21. Jitender K Malik, Himesh Soni, AK Singhai. Synthesis, characterization and evaluation for antifungal activity of substituted diaryl imidazo [2, 1, b]-benzothiazole. J Pharma Res 2013; 7:39-46.

22. Bhupendra Mistry, Rahul V Patel, Young Soo Keum, Doo Hwan Kim. Evaluation of the biological potencies of newly synthesized berberine derivatives bearing benzothiazole moieties with substituted functionalities. J Saudi Chem Soc 2017;21:210-9.

23. Rupali Likhar, P Perumal, Nitin Kolhe, VH Bhaskar, Pratibha Daroi. Synthesis and antioxidant activity of novel 2-aryl substituted benzothiazole derivatives. Int J Curr Pharm Res 2015;7:34-7.

24. AV Subba Rao, Konderu Swapna, Siddiq Pasha Shaik, V Lakshma Nayak, T Srinivasa Reddy, Satish Sunkari, et al. Synthesis and biological evaluation of cis-restricted triazole/tetrazole mimics of combretastatin benzothiazole hybrids as tubulin polymerization inhibitors and apoptosis inducers. Bioorg Med Chem 2017;25:977-99.

25. Kalpesh Parikh, Deepkumar Joshi. Antibacterial and antifungal screening of newly synthesized benzimidazole-clubbed chalcone derivatives. Med Chem Res 2013;22:3688-97.

26. Hatano $T$, Kangawa $H$, Yasuhara $T$, Okuda $T$. Two new favonoids and other constituents in licorice root: their relative astringency and radical scavenging effects. Chem Pharm Bull 1988;36:2090-7.

27. Oyaizu M. Antioxidative activity of browning substances on glucosamine. Japan Nutr 1986;44:307-15.

28. Dinis TCP, Maderia VMC, Almeida LM. Action of phenolic derivatives (acetoaminophen, salycilate, and 5aminosalycilate) as inhibitors of membrane lipid peroxidation and as proxy radical scavengers. Arch Biochem Biophys 1994;315:161-9.

29. Saundane AR, Prabhaker W. Synthesis, Antioxidant, Antimicrobial, Antimycobacterial, and Cytotoxic Activities of Azetidinone and Thiazolidinone Moieties Linked to Indole Nucleus. J Chem 2013. http://dx.doi.org/10.1155/ 2013/ 543815 .

\section{How to cite this article}

- Basavaraj Shivabasappa Naraboli, Jayaprakash Sharanappa Biradar. Synthesis, characterization and biological evaluation of indole derivatives bearing benzimidazole/benzothiazole moiety. Int J Pharm Pharm Sci 2017;9(8): 128-138 